\title{
Senescence in Post-Mitotic Cells: A Driver of Aging?
}

\author{
Thomas von Zglinicki, ${ }^{1,2}$ Tengfei Wan, ${ }^{1}$ and Satomi Miwa ${ }^{1}$
}

\begin{abstract}
Significance: Cell senescence was originally defined by an acute loss of replicative capacity and thus believed to be restricted to proliferation-competent cells. More recently, senescence has been recognized as a cellular stress and damage response encompassing multiple pathways or senescence domains, namely DNA damage response, cell cycle arrest, senescence-associated secretory phenotype, senescence-associated mitochondrial dysfunction, autophagy/mitophagy dysfunction, nutrient and stress signaling, and epigenetic reprogramming. Each of these domains is activated during senescence, and all appear to interact with each other. Cell senescence has been identified as an important driver of mammalian aging.

Recent Advances: Activation of all these senescence domains has now also been observed in a wide range of post-mitotic cells, suggesting that senescence as a stress response can occur in nondividing cells temporally uncoupled from cell cycle arrest. Here, we review recent evidence for post-mitotic cell senescence and speculate about its possible relevance for mammalian aging.

Critical Issues: Although a majority of senescence domains has been found to be activated in a range of postmitotic cells during aging, independent confirmation of these results is still lacking for most of them.

Future Directions: To define whether post-mitotic senescence plays a significant role as a driver of aging phenotypes in tissues such as brain, muscle, heart, and others. Antioxid. Redox Signal. 34, 308-323.
\end{abstract}

Keywords: aging, senescence, post-mitotic

\section{What Is Senescence?}

$\mathbf{C}$ ELLULAR SENESCENCE WAS first discovered and defined by Hayflick and Moorhead in 1961 to describe the phenomenon of limited proliferation capacity in cultured human fibroblasts (50). This replicative senescence (RS) was found to be mainly induced by the dysfunction and critical shortening of telomeres $(9,27,136)$. With more studies being conducted on senescence, the understanding and the definition have been expanded and evolved. For example, stressors, such as DNA damage, oxidative stress, and oncogene activation, were also found to trigger permanent cell cycle arrest and this phenomenon was named as stress-induced premature senescence (SIPS) $(16,82,119,129)$. It was often assumed that RS would be dependent on telomere shortening, whereas SIPS would be telomere length independent. However, this distinction is much less straightforward than originally believed, because stresses can either accelerate telomere shortening $(130,131)$, thus inducing RS prematurely (84, 107), or uncap telomeres without any shortening (51), causing telomere-dependent SIPS. This led to the suggestion that all forms of senescence are cellular stress responses (132), which is now generally accepted (48). Although senescence plays important beneficial roles for tissue remodeling during embryonic development $(96,125)$, in tissue repair and wound healing $(33,75)$ and as a tumor suppressor $(117)$, it has become abundantly clear that the accumulation of senescent cells in multiple, if not all, tissues is a major driver of degenerative phenotypes, disabilities, and diseases during aging $(5,121,140)$.

Recent studies have shown that senescence is much more than an extended cell cycle arrest $(2,48,66,106)$. Several

\footnotetext{
${ }^{1}$ Ageing Research Laboratories, Faculty of Medical Sciences, Biosciences Institute, Newcastle University, Newcastle upon Tyne, United Kingdom.

${ }^{2}$ Molecular Biology and Genetics, Arts and Sciences Faculty, Near East University, Nicosia, Turkey.

(C) Thomas von Zglinicki et al. 2020; Published by Mary Ann Liebert, Inc. This Open Access article is distributed under the terms of the Creative Commons License (http://creativecommons.org/licenses/by/4.0), which permits unrestricted use, distribution, and reproduction in any medium, provided the original work is properly cited.
} 
"building blocks", or phenotypes participate and interplay in senescence, forming positive feedback loops that trigger, develop, and maintain the senescent cell state (Fig. 1).

A persistent DNA damage response (DDR) is probably the most consistently observed feature of senescent cells. Although it can be triggered and maintained by non-telomeric DNA damage (106), the repair deficiency of telomeres (36, $108,112)$ makes them prime candidates for inducers of the senescent DDR (51). The main DDR downstream pathway comprises Ataxia telangiectasia mutated (ATM) and ATM and RAD3-related (ATR) kinases, which belong to the phosphatidylinositol 3-kinase like family of protein kinases

\section{Senescent phenotypes}

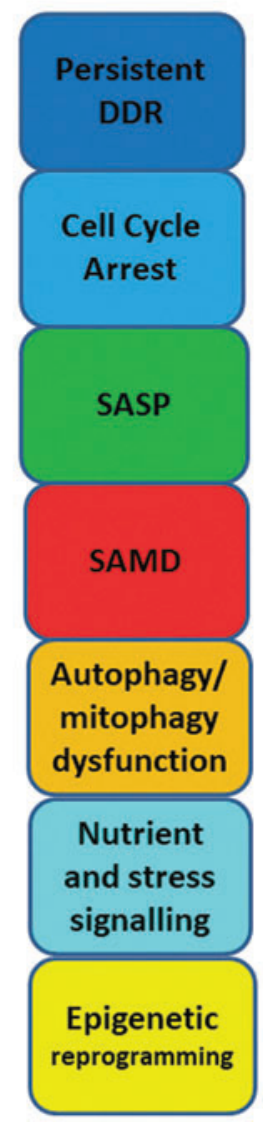

\section{Associated markers}
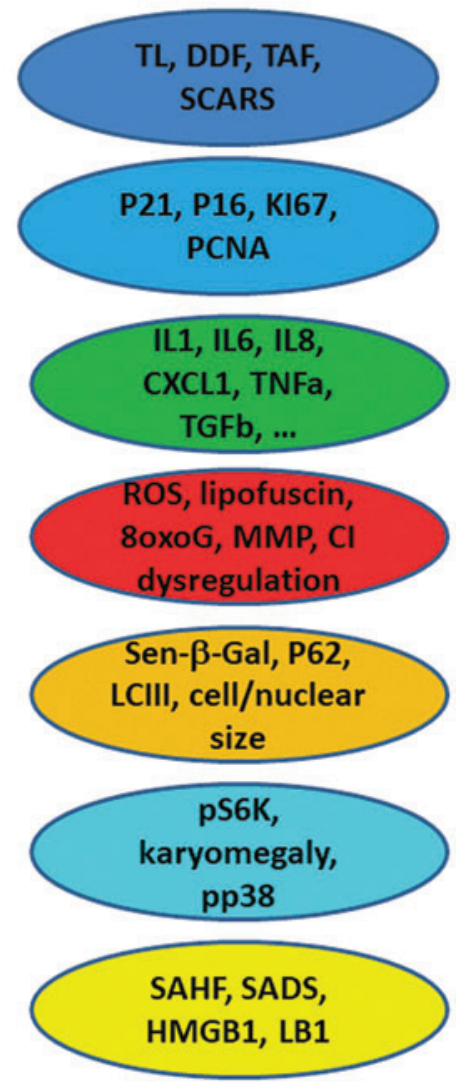

FIG. 1. Phenotypes ("building blocks") of the senescent state and observable markers associated with it. Although all phenotypes are tightly interrelated (not shown), individual phenotypes might be more or less strongly activated in individual senescent cells depending on contexts including senescence inducer, cell type, tissue environment, and others. For each phenotype, there are multiple markers that enable assessment of its involvement in a given senescent state. CI, complex I of the mitochondrial electron transport chain; DDF, DNA damage foci; DDR, DNA damage response; ROS, reactive oxygen species; SADS, senescence-associated distension of satellites; SAHF, senescence-associated heterochromatin foci; SAMD, senescence-associated mitochondrial dysfunction; SASP, senescence-associated secretory phenotype; SCARS, DNA segments with chromatin alterations reinforcing senescence; TAF, telomere-associated foci; TL, telomere length. Color images are available online.
(71, 80). Activated ATM/ATR subsequently activate Chk1 and Chk2, leading to p53 phosphorylation and stabilization and transcriptional induction of the cyclin-dependent kinase (CDK) inhibitor $\mathrm{p} 21$, which then inhibits CDK1/2 and Cyclin A/E complexes $(17,21)$. Their inhibition triggers the hypophosphorylation of $\mathrm{Rb}$, eventually leading to cell cycle arrest (21). In addition, upregulation of gene expression from the CDKN2A locus, mainly p16 $6^{\mathrm{INK} 4 \mathrm{a}}$ and $\mathrm{p} 14^{\mathrm{ARF}}$ (human)/p19 $\mathrm{ARF}$ (mouse), is also an initiator of senescence $(45,63,65)$. Repression of these genes in young cells is released in tissue during aging due to the loss of the polycomb repressive complexes $(11,55)$ via unclear mechanisms. p14/p19 ${ }^{\mathrm{ARF}}$ can inactivate the p53-degrading E3 ubiquitin protein ligase MDM2 and, therefore, maintain p53 at a high level $(45,63)$; whereas $\mathrm{p} 16^{\mathrm{INK} 4 \mathrm{a}}$, a CDK inhibitor, can directly inhibit CDK4, 6 and cyclin D complexes, leading to hypophosphorylation of $\mathrm{Rb}$ and cell cycle arrest $(45,63)$.

Although these pathways initiate the cell cycle arrest, they are usually not sufficient to keep it persistent, which in most cells requires the induction both of the senescence-associated secretory phenotype (SASP) $(2,66)$ and of senescenceassociated mitochondrial dysfunction (SAMD) (106). The SASP comprises a variety of secreted factors. These include preferentially proinflammatory cytokines and chemokines, growth factors, and matrix-modifying factors that are typically driven by nuclear factor- $\kappa \mathrm{B}(\mathrm{NF}-\kappa \mathrm{B})$ and CCAAT/ enhancer binding Protein- $\beta$ transcription factors. A second arm of the SASP is preferentially immunosuppressive and fibrogenic and dependent on Wnt/Notch-1, mainly producing transforming growth factor beta $(\mathrm{TGF} \beta)(52)$; whereas a third damage-associated molecular patterns-dependent arm secretes acetylated HMGB1, heat shock proteins, oxidized lipids, reactive oxygen species (ROS) (e.g., hydrogen peroxide), DNA, and microRNAs, which are often associated with exosomes $(10,22,23,57,79,127)$. The production and secretion of SASP facilitates the maintenance and spreading of senescence by autocrine and paracrine mechanisms. This, on one hand, promotes tissue remodeling and repairing (33, $75,95,96,125)$, but on the other hand, it may contribute to tissue functional decline, age-related tissue degeneration, and tumorigenesis $(22,31,56,67,87)$.

The DDR can initiate SAMD via $\mathrm{p} 38 \mathrm{MAPK}$ and TGF $\beta$ pathways $(8,64,94,106)$ or by SASP via upregulation of NF$\kappa \mathrm{B}(61)$. SAMD is characterized by the concomitant increase in mitochondrial uncoupling (and decrease in mitochondrial membrane potential) together with hyperproduction of ROS (106, 107). Enhanced ROS, in turn, facilitate more DNA damage (106) and SASP secretion (24), thus driving positive, senescence-stabilizing feedback loops. Moreover, SAMD may also promote mechanistic/mammalian target of rapamycin (mTOR) activity independent of nutrition deprivation in senescent cells (99), which contributes to a constant high level of mTOR activity, the nutrient signaling feature of senescence $(19,139)$.

The contribution of mTOR activity to senescence has been hypothesized via the competitive binding of mTOR complexes (mTORC) 1 and 2 to p53, leading to p53 phosphorylation at serine 15 and activation of downstream pathways for the development of senescence (59). A high level of mTOR, especially mTORC1 activity, also suppresses autophagy, which has been suggested in some studies to induce senescence $(62,81,126)$. However, the role of autophagy in 
senescence is still controversial, as senescence can also be promoted by overexpression of the autophagy-related gene ULK3 and suppressed by knockdown of autophagy core genes Atg5 and 7 (101, 138). Importantly, mitochondriaspecific autophagy (mitophagy) is consistently downregulated in senescence, probably due to mTORC1 over-activation (64). This disturbs the balance between mitochondrial biogenesis and turnover, resulting in the accumulation of dysfunctional, damaged mitochondria, leading to more ROS generation and enhanced DDR (30). So far, it is not yet clear whether mitophagy decline is the primary driver for SAMD, or whether SAMD start before declining mitophagy during senescence induction. The accumulation of lipofuscin (nondegradable, highly autofluorescent residual lysosomal content, consisting of cross-linked oxidized lipids and proteins) due to lysosomal overload is also a feature of senescence (123). Lysosomal accumulation of lipofuscin may impair not only autophagy and mitophagy but also the proteasome (122), forming another senescence-stabilizing feedback between multiple features of senescence.

Finally, epigenetic reprogramming and chromatin reorganization occur during senescence, driven, for instance, by mitochondrial retrograde response $(15,107)$ and increased lamin B1 (LB1) degradation by abnormal autophagy $(37,40)$. Markers of epigenetic reprogramming in senescence are: the appearance of senescence-associated heterochromatin foci, domains of facultative heterochromatin that contribute to silencing of proliferation-promoting genes (100), and changes (generally lower levels) in DNA and histone methylation, specifically H3K9me3 and H3K27me3 (115). The epigenetic reprogramming stabilizes other senescence building blocks by promoting mitochondrial dysfunction (47) and SASP production $(18,120)$.

In conclusion, and in agreement with a recent consensus (48), we define cell senescence as a cellular response to a wide variety of stresses (including replicative, oncogenic, oxidative, DNA damage, developmental and other stresses) in which the phenotypes indicated earlier generate a senescence-stabilizing interaction network. Individual phenotypes might be weakly expressed or even absent, as long as the majority of them ensures a sufficiently stable network to maintain the cell senescent state.

Such an understanding of the cell senescence program allows for the temporal separation between a full senescence phenotype and cell cycle arrest. We believe that this may be important in two different ways. First, tumor cells can be induced to senesce by DNA-damaging therapies; however, after having developed a senescent phenotype, some of these revert from cell cycle arrest and resume cycling, but they appear to retain features of SASP, SAMD, and senescent epigenetic reprogramming. Importantly, these features render these previously senescent cells very similar to cancer stem cells, providing increased proliferative and metastatic potential $(26,90,91,133)$. Thus, although it may simply be a semantic distinction whether to call these reverted cells senescent, it would be of major practical importance to understand how some features of senescence can be retained during resumption of proliferation.

Second, this understanding of the senescence program enables us to use the huge accumulated body of knowledge about cellular senescence to better understand stress responses and cell aging mechanisms in post-mitotic cells.
Post-mitotic cells are essential for the function of major tissues, including brain, heart, and skeletal muscle. There are preliminary observations of a senescent phenotype developing and increasing during aging in these tissues, which we will review later. Importantly, how different mechanisms that promote aging, including DNA damage, chronic inflammation, and mitochondrial dysfunction, are interlinked in these tissues is still not well understood. Obviously, if post-mitotic senescence is relevant, translation of knowledge from the cell senescence field might lead to very interesting and novel clues regarding on how such tissues are aging. We will speculatively address this possibility in the final part of this review.

\section{Senescence in Post-Mitotic Cells: The Present Evidence}

To our knowledge, our group published the first study describing a "senescence-like phenotype" in post-mitotic

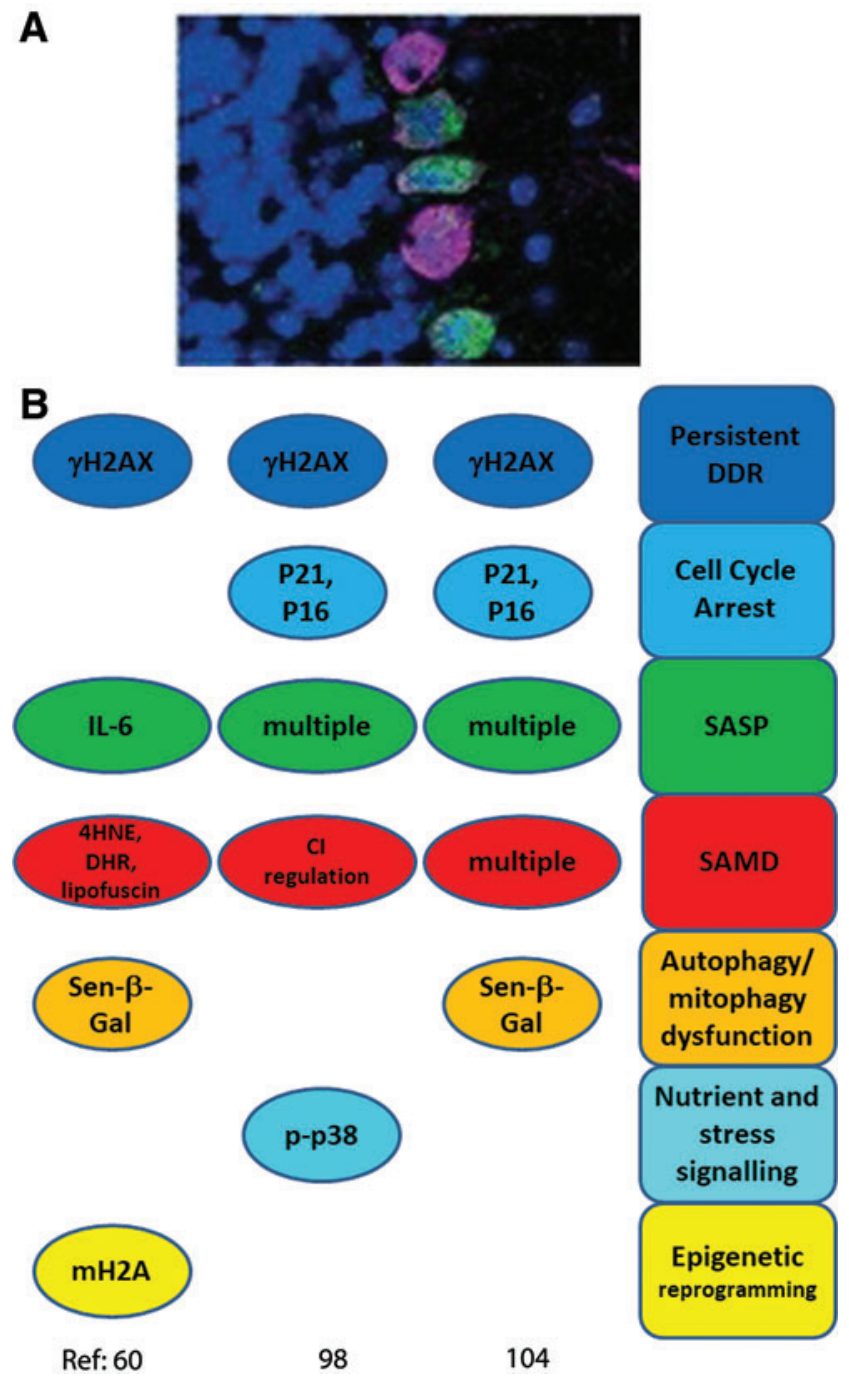

FIG. 2. Senescence markers measured in neurons. (A) Purkinje neurons (labeled by calbindin, purple) in an old (32 months) mouse frequently stain positive for IL-6 (green) (60). (B) Senescence markers observed and senescence phenotypes inferred in neurons $(60,98,104)$. IL, interleukin. Color images are available online. 
cells (60). This work showed that multiple senescence markers were found together in the same neurons (in both the central nervous system and peripheral ones) from old, but not from young, mice. Importantly, by using single- and doublegene knock-out mice, we also showed that accumulation of neurons bearing senescence markers was initiated by a DDR driven by dysfunctional telomeres and was dependent on signaling through p21 (60).

Since this seminal study, accumulation of multiple senescence markers in aging mice has been shown for major post-mitotic cells types residing in different tissues, such as retinal ganglion cells, cardiomyocytes, skeletal myofibers, cochlear cells, and osteocytes (Fig. 2). Most of these results are very recent, and were not covered by other reviews (114). So far, only in the case of neurons, confirmatory data have been presented by independent laboratories $(60,98,104)$; whereas our knowledge about post-mitotic senescence in other tissues is still only based on a single publication per tissue. Moreover, information about some important cell types is completely lacking. For instance, there is no doubt about occurrence and functional relevance of cell senescence in fat tissue $(20,54,128,135)$. However, it remains unclear whether this is restricted to preadipocytes or whether terminally differentiated adipocytes are able/prone to senesce as well. Moreover, to our knowledge, there are no data yet on the role of cell senescence in aging of organisms made up preferentially of post-mitotic cells such as Caenorhabditis elegans or Drosophila melanogaster.

Here, we focus on the question as to what extent a full senescent phenotype has been confirmed in post-mitotic cell types by assessing markers covering the majority or all of the senescence domains indicated earlier. Studies that showed only upregulation of senescence markers in whole tissues without discriminating between post-mitotic and mitotically competent cells were considered only in exceptional cases as confirmatory evidence. We also excluded in vitro studies, as these were generally performed in differentiating stem cell systems, where a clear distinction of proliferation-competent progenitor cells and post-mitotic, terminally differentiated cells is often far from trivial. Results are summarized in Figures 2-6.

\section{Neurons}

Our group previously analyzed the abundance of multiple senescence markers in cerebellar Purkinje neurons, cortical neurons, and neurons of the myenteric plexus during aging of mice between 4 and 32 months (60). More recently, brain neuron senescence was also observed in neurons bearing tau neurofibrillary tangles (NFT) from Alzheimer's disease patients as well as in the brains of an Alzheimer's disease mouse model with elevated tau expression (98). Moreover, senescence phenotypes were reported in the mouse retinal ganglial cell layer under ischemia (104). Colocalization of senescence signals with neuronal markers was shown in two of the studies $(60,104)$. In addition, Musi et al. (98) used microdissection of NFT-bearing human neurons to show transcriptional upregulation of TGF $\beta$-, p38MAPK-, NF- $\kappa \mathrm{B}-$, and p53-regulated genes, and they showed consistent tracking of multiple senescence markers with NFT burden in human disease and in multiple mouse models, including mice treated with senolytics (98). Jurk et al. showed co-localization of

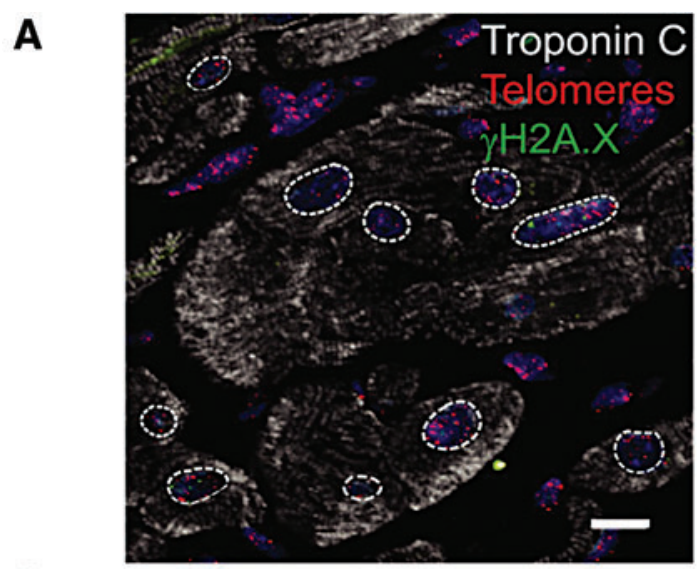

B
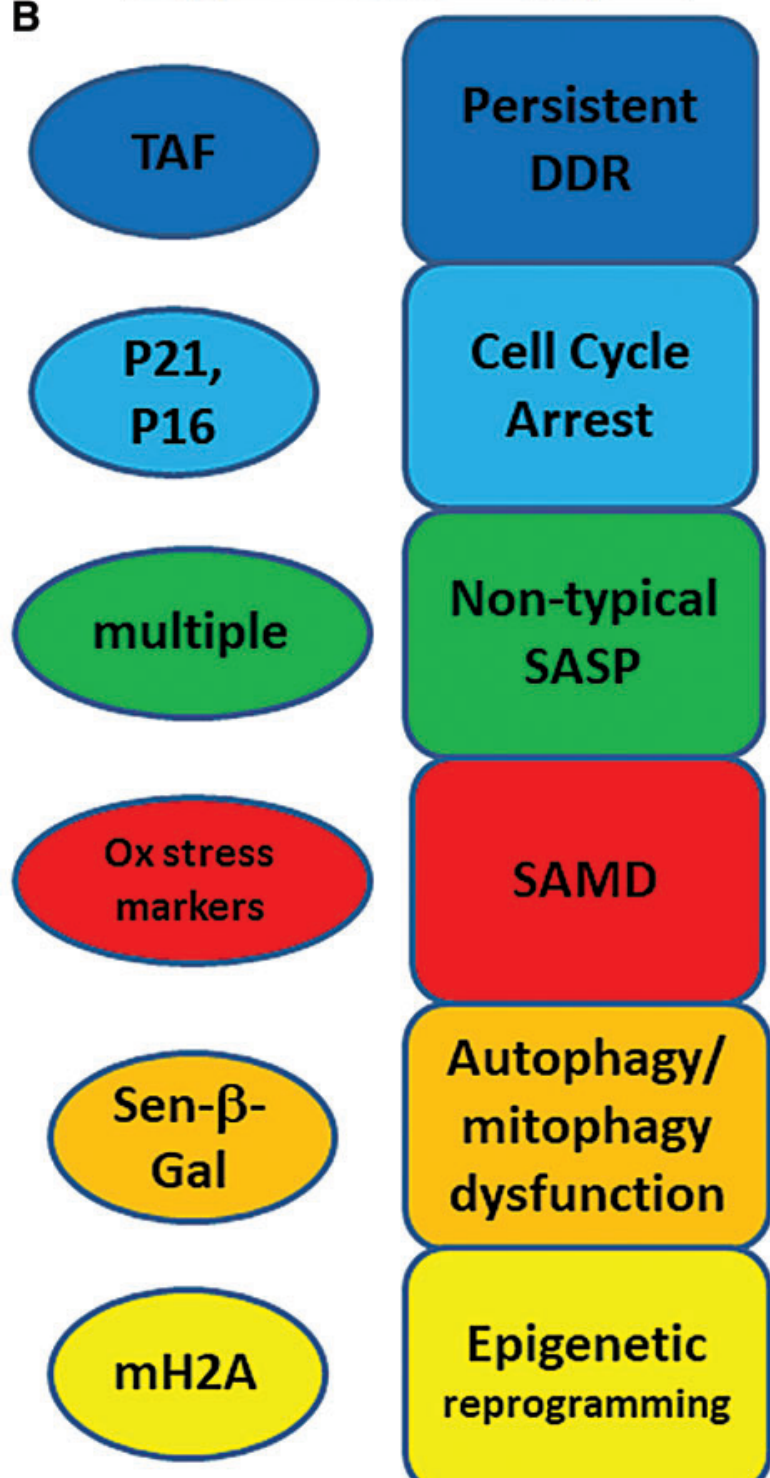

Autophagy/ mitophagy dysfunction

Epigenetic reprogramming

Ref: 4

FIG. 3. Senescence markers measured in cardiomyocytes. (A) Mouse cardiomyocytes (labelled with Troponin $\mathrm{C}$, white) show co-localization of telomeres (red) and $\gamma \mathrm{H} 2 \mathrm{AX}$-positive DDF (green) (4). Cardiomyocyte nuclei are labelled with dotted lines. (B) Senescence markers observed and senescence phenotypes inferred in cardiomyocytes (4). Color images are available online. 


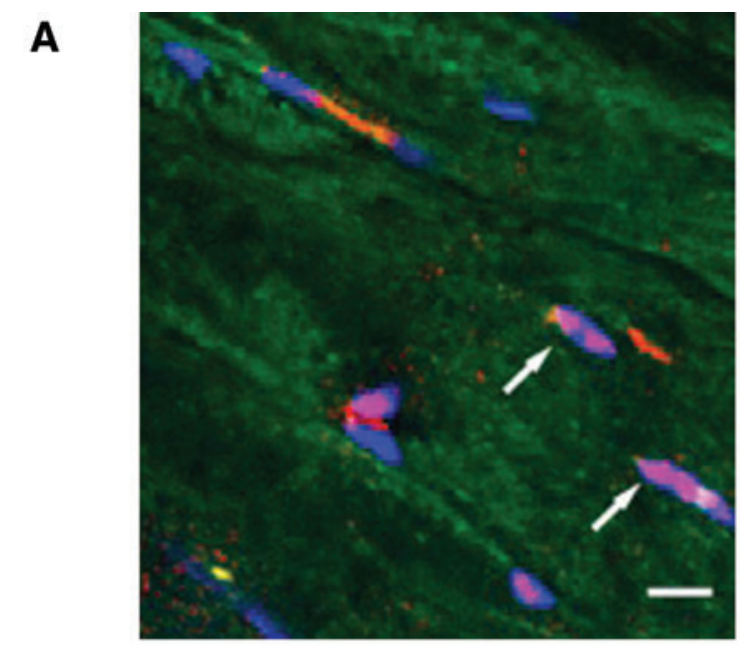

B

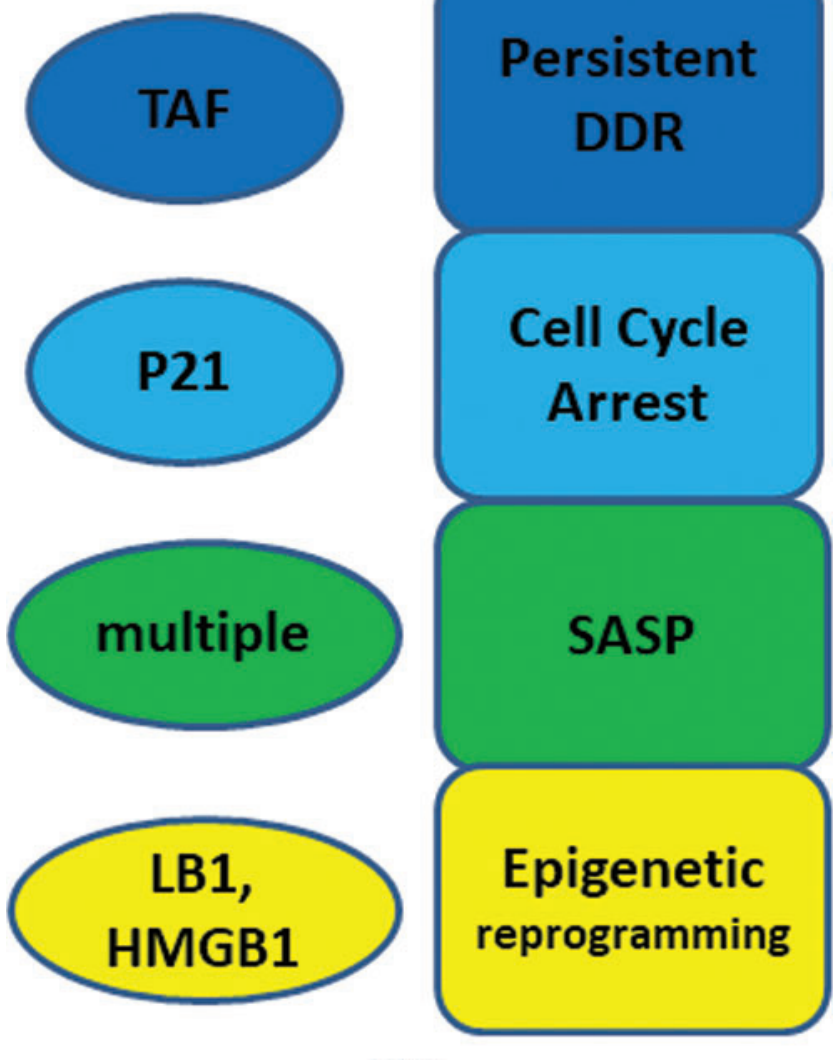

Ref: 28

FIG. 4. Senescence markers measured in skeletal muscle myofibers. (A) Gastrocnemius muscle from a 32month-old mouse. Blue: DAPI, red: p21, green: autofluorescence (28). White arrows indicate p21-positive centrally located nuclei. (B) Senescence markers observed and senescence phenotypes inferred in skeletal myofibers (28). Color images are available online.

multiple senescence markers in the same neurons (60). Interestingly, in the oxygen-induced retinopathy model, retinal ganglion neurons were the first cell type to present senescence markers after stress, and senescence was spread from neurons to retinal microglial cells and the vasculature by bystander signals (104). The following senescence domains were assessed in these studies (Fig. 2).
A

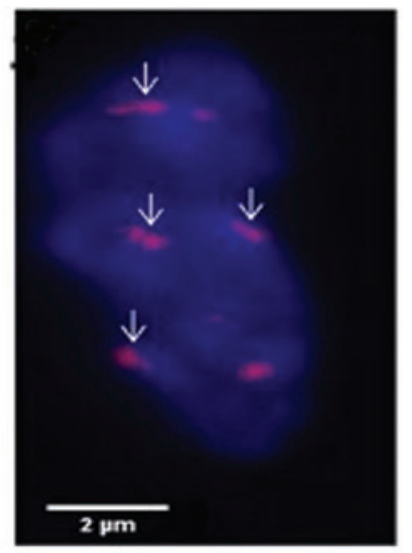

\section{B}
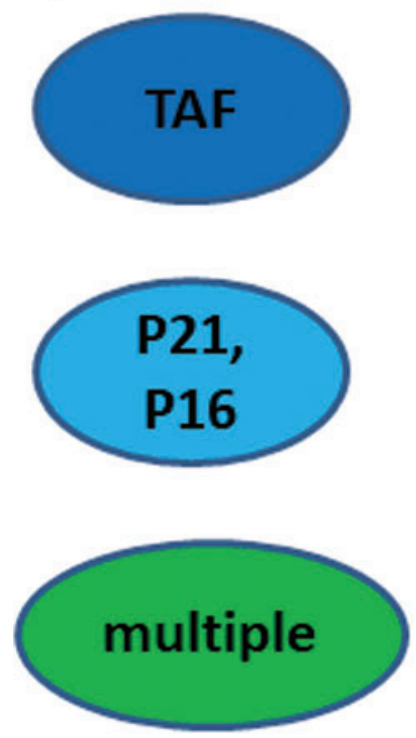

Non-typical

SASP

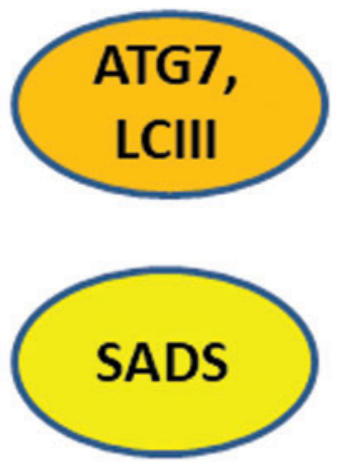

Autophagy/ mitophagy dysfunction

Ref: 38

FIG. 5. Senescence markers measured in osteocytes. (A) SADS (arrows) in an osteocyte freshly isolated from bone marrow of old (24 months) mice (38). (B) Senescence markers observed and senescence phenotypes inferred in osteocytes (38). Color images are available online. 

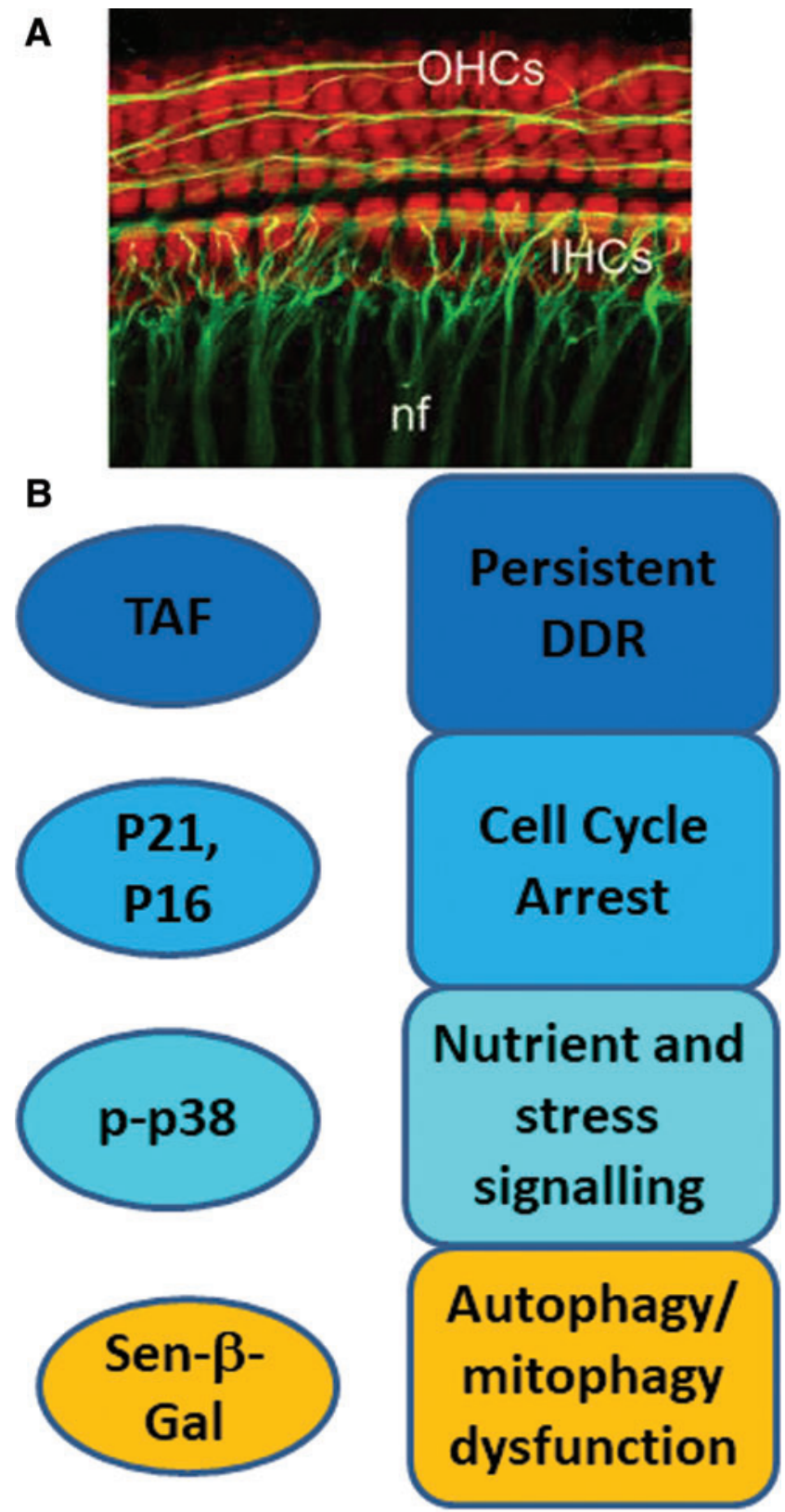

Ref: 6

FIG. 6. Senescence markers measured in post-mitotic cochlear cells. (A) Basal region of cochlear explant stained with myosin 7A (red, outer hair cell [OHC] and inner hair cell [IHC]) and with neurofilament 200 (green, auditory nerve fibers, nf) (6). (B) Senescence markers observed and senescence phenotypes inferred in cochlear cells (6). Color images are available online.

DDR and cell cycle arrest markers. All three studies used $\gamma \mathrm{H} 2 \mathrm{~A}$.X as a DDR marker, which was shown to colocalize with neuronal markers by Jurk et al. and Oubaha et al. $(60,104)$, whereas p53 target genes were elevated in NFT-bearing neurons (98). $\gamma \mathrm{H} 2 \mathrm{~A}$.X-positive Purkinje neurons were shown to be also positive for the lipid peroxidation product 4-hydroxynonenal (4-HNE), suggesting co-activation of DDR and SAMD (60), whereas $\gamma \mathrm{H} 2 \mathrm{~A}$.X co-localized with promyelocytic leukemia protein bodies in retinal ganglion cells (104). A strong $\gamma \mathrm{H} 2 \mathrm{~A} . \mathrm{X}$ signal in Purkinje and cortical neurons was driven by dysfunctional telomeres and was dependent on intact p21 (60). $\gamma \mathrm{H} 2 \mathrm{~A}$.X levels and CDKN2A (p16) expression correlated with NFT burden in both human and tautransgenic mouse brains (98). In retinal ganglion neurons, CDKN1A and CDKN2A expression and p53, p16, and $\gamma$ H2A.X protein abundance were elevated after ischemia (104).

Senescence-associated secretory phenotype. The proportion of Purkinje and cortical neurons with a positive staining signal of proinflammatory cytokine interleukin (IL)6 , a classic SASP member, was found to increase with age in mouse brain neurons and IL-6-producing neurons were shown to be also positive for the oxidative damage marker 4-HNE (60). NF- $\kappa$ B, IL- $\beta$, and CXCL1 were transcriptionally upregulated in NFT-bearing human neurons (98). Oubaha et al. (104) found increased expression of multiple SASP marker genes in the retinal ganglion cells, including matrixdegrading enzyme plasminogen activator inhibitor 1 (Pai1), TGF- $\beta 1$, IL-6, IL-1 $\beta$, and vascular endothelial growth factor $\alpha$. Retinal ganglion cell SASP was dependent on semaphorin 3A (SEMA3A) expression, and suppression of SEMA3A was able to block paracrine propagation of senescence (104).

Senescence-associated mitochondrial dysfunction. In old mice, Purkinje and cortical neurons accumulated the lipid peroxidation product 4-HNE and more ROS were produced in enteric neurons as shown by increased fluorescence from the ROS indicator dye dihydrorhodamine-123 (60). Moreover, increased autofluorescence in brain neurons of old mice indicated accumulation of lipofuscin, another indicator of oxidative stress and damage $(13,14)$. In hippocampus and cortex of NFT-bearing tau transgenic mice, complex I- and -II-linked ATP production was decreased without change of mitochondria mass (98), indicating impaired mitochondrial function. Although the study by Oubaha et al. (104) used oxidative stress to induce retinopathy and senescence, SAMD indicators were not measured.

Autophagy dysfunction. Senescence-associated betagalactosidase (SA- $\beta$-Gal) reporting lysosomal overload and thus the possibility of autophagy dysfunction, is a frequently used marker for senescence and was assessed in all three studies. SA- $\beta$-Gal staining was enhanced in brain, mesenteric and retinal ganglion neurons $(60,104)$. Although no SA- $\beta$ Gal staining was found in NFT-bearing mouse brains, the expression of the GLB1 gene encoding for $\beta$-galactosidase was enhanced (98). In addition, the previously mentioned lipofuscin accumulation (60) can also be considered as a marker for autophagy dysfunction as lipofuscin accumulation inhibits both autophagic flux and proteasomal protein degradation $(53,122,124)$.

Nutrient and stress signaling. p38MAPK is a sensor and responds to a wide range of different stresses, which can initiate senescence (41). High levels of phosphorylated p38MAPK were observed in neurons in aging mice, especially those that were also positive for 4-HNE (60), and p38MAPK and downstream regulated genes were upregulated in NFT-bearing human neurons (98). In retinal ganglion neurons, p38MAPK was not assessed but high levels of phosphorylated inositol-requiring enzyme $1 \alpha$ (IRE1 $\alpha$ ), a 
marker for endoplasmic reticulum (ER) stress, were observed (104). In fact, retinal senescence was dependent on the endoribonuclease activity of IRE1 $\alpha$ (104). ER stress had been implicated in different senescence modes, including oncogene $\mathrm{HRAS}^{\mathrm{G} 12 \mathrm{~V}}$-induced senescence (35) and of chondrocyte senescence in osteoarthritis (77). Markers of nutrient signaling have to our knowledge not been assessed in the context of neuron senescence.

Epigenetic modification. Markers for epigenetic reprogramming in neurons were only assessed in one of the studies. Jurk et al. (60) showed enhanced nuclear granularity for the heterochromatin-associated histone variant $\mathrm{mH} 2 \mathrm{~A}$ in Purkinje and cortical neurons from old mice.

\section{Cardiomyocytes}

Recent studies indicate that human and mouse cardiomyocytes retain the ability to divide, but do so very rarely leading to turnover rates of $<1 \%$ in adulthood $(7,111,118)$. A recent paper showed that mouse and human cardiomyocytes acquire senescence-like phenotypes during aging from 3 to 30 months in mice and from adult (46-65 years) to old (74-82 years) age in humans. This was characterized by persistent DNA damage at telomeres, p21 and p16 activation, and a noncanonical SASP (4). In detail, the following senescence domains were considered (Fig. 3).

DDR and cell cycle arrest markers. Telomere-associated DNA damage foci (telomere-associated foci [TAF]) can be instigated by DNA damage even at long telomeres and are a persistent form of DNA damage $(42,51)$ and thus potent inducers of a senescent phenotype (61). They were found to trigger senescence regardless of telomere length both in vivo in old mouse and human hearts and in vitro in cultivated mouse embryonic cardiomyocytes. Independence of telomere length strongly indicated that the cardiomyocytes that underwent this type of aging were, in fact, post-mitotic (4). Increased TAF frequencies were paralleled by enhanced transcription of cell cycle arrest markers $\mathrm{p} 21, \mathrm{p} 16^{\mathrm{INK} 4 \mathrm{a}}$, and $\mathrm{p} 15^{\mathrm{INK} 4 \mathrm{~b}}$ and increased $\mathrm{p} 21$ protein abundance in cardiomyocytes from old mice. Transgenetically induced telomeric DNA double-strand breaks remained persistent and were able to induce further markers of senescence in cardiomyocytes, whereas non-telomeric DNA damage was repaired within a few hours and did not cause a senescent phenotype (4).

Autophagy dysfunction and cellular morphology change. Increased SA- $\beta$-Gal activity was found in the hearts of old mice and was localized solely to cardiomyocytes (4), which showed that autophagy dysfunction occurred specifically in the post-mitotic cells. Telomeric DNA double-strand breaks, induced in cultured rat neonatal cardiomyocytes after transfection with a telomere-targeting endonuclease, were sufficient to induce increased SA- $\beta$-Gal activity (4). Moreover, cardiomyocyte hypertrophy was found in vivo in old mice and in vitro in cultivated rat neonatal cardiomyocytes under all senescence-inducing conditions, possibly due to elevated Myh7 and Acta1 gene expression (4).

Senescence-associated mitochondrial dysfunction. Mitochondrial dysfunction was evidenced by decreased ex- pression of many mitochondrial genes, especially those related to mitochondrial inner membrane and electron transport chain (4). Expression of MnSOD (SOD2) and catalase was reduced in old cardiomyocytes, whereas the expression of monoamine oxidase $\mathrm{A}$, an enzyme promoting oxidative stress, was increased (4). Further, frequencies of cardiomyocytes positive for the markers of ROS-mediated damage 4-HNE and 8-oxodG were also increased in old mice (4).

Senescence-associated secretory phenotype. Classical proinflammatory SASP markers such as IL-6 and CXCL1 were found to be elevated in old mice whole hearts (103) but not in purified cardiomyocytes showing telomeric DNA damage, SA- $\beta$-Gal activity, and SAMD. In contrast, these cells displayed a noncanonical SASP characterized by enhanced expression of Edn3, TGF $\beta 2$, and Gdf15 with enhanced Edn 3 expression specific to old cardiomyocytes. This SASP (especially TGF $\beta 2$ ) was antiproliferative, profibrotic, and prohypertrophic in co-cultured cells (4).

Epigenetic modification. Senescence-associated distension of satellites (SADS) has been suggested to be an early chromatin modification in senescence, which frequently occurs in replicative and oncogene-induced senescence (25). Increased frequencies of SADS-positive cardiomyocytes were found in the hearts of old mice (4).

\section{Skeletal muscle myofibers}

In the context of a study of the bystander effects of senescent cells in vivo, our group recently reported the induction of multiple markers of senescence in gastrocnemius and biceps femoris muscle of mice aging from 8 to 32 months. Myofiber senescence marker correlated with low fiber diameter, an indicator of muscle aging and sarcopenia at both interindividual and single fiber levels (28). A limitation of this study is that myofiber nuclei were only identified by their position within a fiber as outlined by wheat germ agglutinin staining, but satellite cells were not excluded by positive staining with a stem cell marker. However, satellite cell frequencies were regarded as too low to significantly falsify counts of myofiber nuclei bearing senescence markers. The following senescence domains were assessed (Fig. 4).

DDR and cell cycle arrest markers. In old mice skeletal muscles, there was a higher frequency of TAF-positive nuclei as well as a tendency toward more p21-positive nuclei (28). This result was strengthened by an experiment, in which senescent cells were xenotransplanted into muscle of immunodeficient NOD scid gamma mice. In this experiment, significant higher frequencies of TAF- or p21-positive myofiber nuclei were found in the vicinity of the transplanted senescent cells, but not next to nonsenescent transplanted cells. Moreover, p16 and p21 mRNAs were increased in old muscles.

Senescence-associated secretory phenotype. The proinflammatory SASP genes IL- $1 \alpha$, IL- $1 \beta$, IL- 6 and tumor necrosis factor alpha (TNF- $\alpha$ ) were enhanced at mRNA level in old muscles. However, no evidence was found for 
enhanced protein levels of proinflammatory cytokines in either muscles from old mice or in the myofibers in muscles transplanted with senescent cells. Reasons for this discrepancy were not clear, and potential non-proinflammatory SASP components were not evaluated in this study (28).

Senescence-associated mitochondrial dysfunction. The article used Sudan Black B (SBB) staining as an indicator of oxidative damage as described (44). However, in skeletal muscle, the SBB staining pattern is primarily determined by fiber type, with oxidative fibers positive for SBB in contrast to glycolytic fibers. Therefore, a reliable assessment of mitochondrial dysfunction as stress response in any fiber type has not yet been performed.

Epigenetic modification. Nuclear exclusion of HMGB1 and decrease of LB1 at the nuclear lamina are wellestablished senescence markers (32, 40). Both decreased HMGB1 nuclear staining and increased heterogeneity of the LB1 distribution over the nuclear lamina were found in myocyte nuclei of old mice. LB1 heterogeneity over the nuclear lamina was also increased in the vicinity of xenotransplanted senescent cells (28).

\section{Osteocytes and osteoblasts}

Farr et al. separately isolated T cells, myeloid cells, osteoblast progenitors, and, important in the present context, mature post-mitotic osteocytes and osteoblasts from bone marrow in young (6 months) and old (24 months) mice (38). A range of senescence markers was measured in these fractions without any in vitro subculturing of the cells (Fig. 5). In general, increases of senescence markers observed in postmitotic osteoblasts and osteocytes were at least comparable in magnitude if not larger than those seen in progenitor and hematopoietic lineage cells.

DDR and cell cycle arrest markers. The percentage of TAF-positive osteocytes increased from $<20 \%$ in young mice to almost $90 \%$ in old ones together with an increase in p21 gene expression. $\mathrm{p} 16^{\text {Ink4a }}$ mRNA levels were found to increase dramatically in both osteocytes and osteoblasts isolated from trabecular and cortical bones of both old female and male mice. In addition, p16 ${ }^{\text {Ink } 4 a}$ and p21 mRNA expression was also increased in bone biopsies of old female human donors, although this analysis did not distinguish cell types (38).

The expression of a panel of 36 established SASP genes was investigated by Real Time quantitative polymerase chain reaction (RT-qPCR) on different types of cells isolated from old and young mouse bones $(1,22,23)$. Very few of these SASP factors were significantly altered in B cells, T cells, osteoblast progenitors, or osteoblasts. However, 23 of the 36 SASP genes analyzed were significantly increased in old versus young osteocytes. Twelve SASP genes out of the same 36 gene panel were also enhanced (at $p<0.05$ ) at whole tissue level in bone biopsies from old versus young human donors, although an enrichment analysis for the whole gene set did not result in statistical significance (38).

Autophagy dysfunction. The expression of two autophagy marker genes, Atg7 and Map1lc3a (commonly known as LC3) was measured by RT-qPCR. Lower expression of both in osteocytes (but not osteoblasts) from old mice was found (38).

Epigenetic modification. The presence of SADS was analyzed as a marker for chromatin reorganization in senescence, and an increase from $2 \%$ to $11 \%$ of SADS-positive osteocytes was found in the bone cortices of old mice (38).

\section{Cochlear hair cells}

Recently, Benkafadar et al. reported the upregulation of multiple markers of cell senescence in the cochlea of prematurely aging SAMP8 mice (6). Proliferation-competent support and progenitor cells are present in the cochlea, whereas major cell types are the post-mitotic sensory hair cells and ganglion neurons. Some of the analyzed markers (e.g., SA- $\beta$-Gal staining) were localized by the authors to the hair cells in the organ of Corti and to spiral ganglion neurons, whereas others were only assessed in whole tissue homogenates. However, the authors also studied oxidative stress-induced senescence in explanted and in vitro cultured cochleae and organs of Corti, again showing preferential senescence induction in hair cells, especially those of the outer layer. Markers for the following senescence domains were assessed (Fig. 6).

DDR and cell cycle arrest markers. Significant increases of p21, p16, p53, and p-Chk2 protein levels were found in whole cochlear extracts from SAMP8 mice compared with slow-aging SAMR1 mice starting from 6 to 12 months of age (6). Activation of a DDR in the hair cells was confirmed in the ex vivo model, showing increased numbers of $\gamma \mathrm{H} 2 \mathrm{~A} . \mathrm{X}$ and 53BP1 foci in outer and inner hair cell nuclei at 3 days after oxidative stress. This result was confirmed by Western blot on whole cochlear extracts (6). Moreover, higher levels of the DNA nucleotide excision repair protein DDB2 (DNA binding protein 2) were also found in these cells, associated with increased levels of phosphorylated Chk2, p53, and p21 (6).

Senescence-associated mitochondrial dysfunction. In whole cochlear extracts from aged SAMP8 mice, lower protein levels of MnSOD and the oxidant resistance regulator Nrf2 and higher levels of p66Shc and phospho-p66Shc, a negative regulator of MnSOD (69) whose upregulation can lead to higher oxidative stress (46), were found. In isolated cochlear extracts at 3 days after oxidative challenge, MnSOD and catalase protein and activity were enhanced, as were p66Shc and phospho-p66Shc and malondialdehyde content, indicating persistently increased oxidative stress. Whether this was associated with mitochondrial dysfunction as in fibroblast stress-induced senescence (106) has not been established.

Autophagy dysfunction. SA- $\beta$-Gal activity was associated with inner and outer hair cells and spiral ganglion cells in both in vitro cultured cochlea after oxidative stress and in cochleae from aged SAMP8 mice. In addition, higher levels of phosphorylated Beclin 1, Rab7, and LC3 II were found in cochlear extracts of old SAMP8 mice and in stressed cochlea in vitro (6). These results suggested an increased autophagy with inefficient lysosomal flux clearance, indicating autophagy dysfunction. 
Stress signaling. At 3 days after oxidative stress, cochlear hair cells became senescent, marked by the increased levels of p38 and its phosphorylated form (6).

\section{Conclusions}

Three independent laboratories have shown different types of neurons expressing markers for multiple senescence domains under different age-related stressors. Markers for each of the senescence-associated domains shown in Figure 1 were found in stressed and/or aged neurons (Fig. 2), and some of these markers were co-localized in the same cells (60). Altogether, the data provide robust evidence that neurons do respond to age- or disease-associated stress by senescence, even when they have long before ceased to proliferate.

Evidence related to cell senescence in other post-mitotic cell types is less strong. Results per cell type have not yet been independently confirmed. Markers for four to six of the seven senescence domains identified in Figure 1 were assessed in each of the examined non-neuronal post-mitotic cell types (Figs. 3-6). Only DDR markers were measured in all cell types and were found to be consistently activated. Secretions of the canonical proinflammatory SASP were not confirmed in heart nor skeletal muscles, and there could be cell-type specific differences. On the other hand, variations of the SASP have been observed as well during senescence of proliferation-competent cells, indicating that the SASP is modified by a multiplicity of factors, including engagement of check-point proteins p53, p21, and p16, mitochondrial (dys) function, response kinetics, and cell type $(17,52)$. Together, we feel that the evidence is good enough to conclude that probably all post-mitotic cells have the ability to mount a senescence response, and that they probably do so in measurable quantities during aging and under physiologically and pathologically relevant stresses.

\section{How Important Is Senescence of Post-Mitotic Cells to Understand Mammalian Ageing In Vivo?}

The pathogenic roles of senescent cells are now well recognized. Growing evidence shows that selective elimination of senescent cells, or reducing the SASP and thus senescenceinduced bystander effects, improves a wide range of ageassociated and/or pathologic conditions (121). This may also hold for post-mitotic cell senescence. For example, in a model of ischemic retinopathy, retinal ganglion cells became senescent and the resulting SASP caused pathologic angiogenesis, which worsened the retinopathy. Metformin, which reduced the SASP, prevented the adverse effects of ischemic retinopathy (104). It is less clear whether and to what extent post-mitotic senescent cells affect normal tissue physiological functions, especially aging. However, there are striking similarities between cell senescence, including post-mitotic senescence, and aging phenotypes as observed in tissues composed to a large extent of post-mitotic cells. It might thus be speculated that a better understanding of the cellular regulatory pathways that govern the senescent stress response might lead to a deeper comprehension of, and better possibilities for, interventions into age-associated functional decline in post-mitotic tissues. Keeping in mind the present limitations of knowledge, we will now discuss some of the possible relevance of post-mitotic senescence for aging, using myofiber senescence and muscle aging as an example.

\section{Ageing of skeletal muscle}

Skeletal muscle not only has a primary role in locomotion and in the maintenance of posture but also shapes metabolic homeostasis by taking up glucose and oxidizing fatty acids. There are four major fiber types in mammalian muscle: slow (type 1) and three fast types (2A, 2X, and 2B). Each type is characterized by the expression of one specific isoform of the myosin heavy chain, which is the main determinant of their contractile properties. Fiber types differ in their metabolic profiles, ranging from slow/oxidative to fast/glycolytic (116).

One prominent change in skeletal muscle during aging is the decline of skeletal muscle mass and function. It leads to gait instability and increased risk of falls (137) and is a primary cause of sarcopenia, a leading cause of death in elderly (68). By age 70, the mean cross-sectional area of skeletal muscle is reduced by $25 \%-30 \%$ and muscle strength diminishes by $30 \%-40 \%$ (109). These changes are believed to be both due to a decrease in the number of muscle fibers and due to atrophy and weakening of those remaining $(12,73,74)$.

Age-related sarcopenia in humans affects fast fibers more strongly than slow ones $(3,72)$. Maintenance of muscle mass is achieved by anabolic and catabolic balance. The main anabolic stimulation comes from muscle contraction to which the muscle cells respond by adaptive mechanisms. Resistance exercise is known to counteract the loss of muscle mass and function; however, aged muscle fails to readily adapt to exercise and this anabolic resistance is proposed to play a major role in sarcopenia.

Mitochondrial activity in skeletal muscles has long been known to correlate with exercise capacity (39), with a recent observation showing that especially with respect to complex I (43), suggesting mitochondrial function is critical for skeletal muscle function. Mitochondrial content has widely been observed to decrease with age in skeletal muscles $(58,78$, 97). Skeletal muscle mitochondria also undergo functional changes with age; respiratory coupling decreases, and the rate of ROS release per unit of mitochondrial protein increases $(49,83)$. Therefore, decreases in both quality and quantity of mitochondria contribute to the overall loss of mitochondrial function in aged skeletal muscles.

\section{Is post-mitotic senescence relevant for skeletal muscle aging?}

Senolytic treatment was shown to be effective in preserving muscle fiber diameter in skeletal muscles (5). Mechanistically, this has been assumed to be caused by either systemic reduction of SASP factors or improved stem (satellite) cell function. However, do senescent myocytes also account for development of sarcopenia and other features of aged skeletal muscles?

Our current understanding of the nature of post-mitotic senescence in general and in muscle specifically is limited. This poses a number of unanswered questions. For instance, what are the actual proportions of cells that senesce in different muscles? Are different myofiber types differently susceptible to senescence? There appears to be a cellular state of transition from normal to senescent (106), but how long does this transition last in myofibers in vivo? How efficient is immunosurveillance of senescence in muscle? How long do senescent myofibers persist in the tissue? When senescent cells were implanted into skeletal muscles 
in immune-deficient mice, neighboring cells became senescent within about 1 month (28). However, during normal, healthy aging in vivo endogenous stress factors might be different and the immune system is generally competent, leading to possibly a different time course of senescence development.

Despite these limitations, it appears well possible that senescent myocytes may account for the development of sarcopenia in multiple ways. Importantly, an association between the presence of senescence markers in myocyte nuclei and low fiber diameter in the vicinity has been established (28). During mammalian aging, fast glycolytic fibers undergo a significant size reduction in aging, unlike slow fibers (97). Interestingly, our preliminary data in a premature aging mice model show higher frequencies of nuclei bearing the senescence marker telomere-associated DNA damage foci in glycolytic fibers than in slow/oxidative fibers. However, it is unknown whether induction of a senescent stress response caused fiber atrophy or conversely, was due to it.

The main anabolic stimulation important for maintenance of muscle mass derives from muscle contraction to which the muscle cells respond. These adaptive response mechanisms include those through redox-signaling pathways medicated by contraction-mediated increases in the generation of superoxide and nitric oxide by skeletal muscle fibers (85). However, aged muscle fails to adapt to exercise mainly because of an attenuated response to ROS-stimulated redox signaling, and this anabolic resistance is proposed to play a major role in sarcopenia. Elevated levels of oxidative stress cause the chronic activation of multiple signaling pathways, contributing to the blunted response of aged muscle to contraction-medicated signals. In both single fibers and isolated mitochondria from skeletal muscles, ROS were found to increase with age $(83,105)$. Although there are no empirical data yet on ROS levels specifically in senescent myocytes, elevated ROS production in senescent cells, in general, is well documented $(61,93,106)$. Thus, it is very possible that senescent myocytes contribute to the elevated oxidative stress in aging muscle tissue. However, as we do not know the proportion of senescent myocytes in aged skeletal muscles, we cannot yet establish the relative importance of the contribution of senescent myocytes to oxidative stress in aged muscles.

Mitochondrial dysfunction (SAMD), characterized by increased mitochondrial biogenesis, increased levels of ROS, and reduced coupling (106) is a major senescence domain. It is related to decreased mitophagy $(30,64)$. In isolated mitochondria from skeletal muscles of aged animals, functional properties consistent with a typical SAMD were observed, namely increased ROS release and decreased coupling (49, 83). Dietary restriction and dietary restriction mimetics, including rapamycin, reduced mitochondrial ROS levels and improved mitochondrial coupling $(92,93)$. Correspondingly in vitro, rapamycin reduced both SAMD and SASP in senescent fibroblasts $(24,34)$.

In fibroblast cell senescence in vitro, increased levels of mitochondrial biogenesis markers such as PGC- $1 \alpha / \beta$ and increased mitochondrial mass were observed $(70,106)$. However, in contrast, in aged skeletal muscles, decreased mitochondrial mass in both fast and slow fibers was found (97). Currently, it is unclear whether mitochondrial mass increase is a universal feature of the senescent phenotype. A decrease in mitophagy seems to be the essential factor causing mitochondrial mass increase in senescing fibroblasts (30). An experimental assessment of the balance between mitochondrial biogenesis and mitophagy during myofiber senescence will be necessary to clarify this point.

SASP is another senescence domain that might also contribute to sarcopenia. In fact, inflammation has been proposed as a key driver of skeletal muscle aging $(29,85)$. For example, exposure of skeletal muscle to TNF- $\alpha$ results in muscle weakness associated with a loss of total muscle protein through increased NF- $\kappa \mathrm{B}$ activation, at least partly mediated by ROS signaling (76). In aged human muscle, increased levels of NF- $\kappa \mathrm{B}$ have been suggested as a contributing cause to the anabolic resistance in aging (113). However, the supporting data are inconsistent, because some papers reported increases in gene expression levels for proinflammatory cytokines in human skeletal muscles with age $(86,88,110)$, whereas others did not (89). We found elevated gene expression levels of proinflammatory cytokines IL- $1 \alpha$, IL- $1 \beta$, IL-6, and TNF- $\alpha$ in old mice skeletal muscles but no differences to young animals at protein level (28). In cardiomyocytes, an atypical antiproliferative, non-inflammatory SASP was found (4). The composition of the SASP in senescent skeletal myofibers, and its potential contribution to chronic inflammation in aged muscle still needs to be established. Moreover, skeletal muscle has recently been proposed to be a potential source of a diverse range of cytokines, termed myokines (102, 134). Exercise-stimulated myokines, such as IL-15, can have beneficial effects on the immune system and on control of adiposity (102). Whether myofiber senescence impacts myokine expression and secretion, and the role of myokines in skeletal muscle aging are important topics for future studies.

\section{Conclusions}

There is good evidence for a senescent phenotype as stress response in post-mitotic cells, including skeletal myofibers. It is possible that post-mitotic cell senescence has functional relevance in tissue aging, but the evidence for this is still weak. Important open questions are:

1. The phenotype of senescent myofibers needs to be better characterized. How do they differ from fibroblasts? What are the functional implications? Surprisingly little evidence exists for senescent myofibers or old muscle tissues being proinflammatory.

2. The actual proportions of senescent myocytes in aging muscles need to be determined. This requires improved quantitative techniques for senescent cell detection ex vivo.

3. Systemic senolytic intervention has been shown to be effective in postponing sarcopenia $(5,140)$. As SAMD is an important senescence domain, this might have resulted in improved mitochondrial function in vivo. Senolytic or senostatic interventions might have better potential to improve mitochondrial function than many other drugs that increase mitochondrial biogenesis. The impact of anti-senescence interventions on muscle mitochondrial function needs to be assessed. 


\section{Funding Information}

Work leading to this review was supported by Cancer Research United Kingdom (Pioneer grant C12161/A24009 to T.v.Z.), BBSRC (grant no. BB/S006710/1 to T.v.Z.) and by Innovate United Kingdom (KTP No 11272 to S.M. and T.v.Z.). T.W. is funded by a Medical Research Council Versus Arthritis Centre for Integrated Research into Musculoskeletal Ageing grant to S.M.

\section{References}

1. Acosta JC, Banito A, Wuestefeld T, Georgilis A, Janich P, Morton JP, Athineos D, Kang TW, Lasitschka F, Andrulis M, Pascual G, Morris KJ, Khan S, Jin H, Dharmalingam G, Snijders AP, Carroll T, Capper D, Pritchard C, Inman GJ, Longerich T, Sansom OJ, Benitah SA, Zender L, and Gil J. A complex secretory program orchestrated by the inflammasome controls paracrine senescence. Nat Cell Biol 15: 978-990, 2013.

2. Acosta JC, O'Loghlen A, Banito A, Guijarro MV, Augert A, Raguz S, Fumagalli M, Da Costa M, Brown C, Popov N, Takatsu Y, Melamed J, d'Adda di Fagagna F, Bernard D, Hernando E, and Gil J. Chemokine signaling via the CXCR2 receptor reinforces senescence. Cell 133: 10061018, 2008.

3. Andersen JL. Muscle fibre type adaptation in the elderly human muscle. Scand J Med Sci Sports 13: 40-47, 2003.

4. Anderson R, Lagnado A, Maggiorani D, Walaszczyk A, Dookun E, Chapman J, Birch J, Salmonowicz H, Ogrodnik M, Jurk D, Proctor C, Correia-Melo C, Victorelli S, Fielder E, Berlinguer-Palmini R, Owens A, Greaves LC, Kolsky KL, Parini A, Douin-Echinard V, LeBrasseur NK, Arthur HM, Tual-Chalot S, Schafer MJ, Roos CM, Miller JD, Robertson N, Mann J, Adams PD, Tchkonia T, Kirkland JL, Mialet-Perez J, Richardson GD, and Passos JF. Length-independent telomere damage drives postmitotic cardiomyocyte senescence. EMBO J 38 [Epub ahead of print]; DOI: 10.15252/embj/2018100492, 2019.

5. Baker DJ, Wijshake T, Tchkonia T, LeBrasseur NK, Childs BG, van de Sluis B, Kirkland JL, and van Deursen JM. Clearance of p16Ink4a-positive senescent cells delays ageing-associated disorders. Nature 479: 232-236, 2011.

6. Benkafadar N, Francois F, Affortit C, Casas F, Ceccato JC, Menardo J, Venail F, Malfroy-Camine B, Puel JL, and Wang J. ROS-induced activation of DNA damage responses drives senescence-like state in postmitotic cochlear cells: implication for hearing preservation. Mol Neurobiol 56: 5950-5969, 2019.

7. Bergmann O, Zdunek S, Felker A, Salehpour M, Alkass K, Bernard S, Sjostrom SL, Szewczykowska M, Jackowska T, Dos Remedios C, Malm T, Andra M, Jashari R, Nyengaard JR, Possnert G, Jovinge S, Druid H, and Frisen J. Dynamics of cell generation and turnover in the human heart. Cell 161: 1566-1575, 2015.

8. Bitto A, Sell C, Crowe E, Lorenzini A, Malaguti M, Hrelia $\mathrm{S}$, and Torres C. Stress-induced senescence in human and rodent astrocytes. Exp Cell Res 316: 2961-2968, 2010.

9. Bodnar AG, Ouellette M, Frolkis M, Holt SE, Chiu CP, Morin GB, Harley CB, Shay JW, Lichtsteiner S, and Wright WE. Extension of life-span by introduction of telomerase into normal human cells. Science 279: 349-352, 1998.

10. Borghesan M, Fafian-Labora J, Eleftheriadou $O$, Carpintero-Fernandez P, Paez-Ribes M, Vizcay-Barrena
G, Swisa A, Kolodkin-Gal D, Ximenez-Embun P, Lowe R, Martin-Martin B, Peinado H, Munoz J, Fleck RA, Dor Y, Ben-Porath I, Vossenkamper A, Munoz-Espin D, and O'Loghlen A. Small extracellular vesicles are key regulators of non-cell autonomous intercellular communication in senescence via the interferon protein IFITM3. Cell Rep 27: 3956-3971.e6, 2019.

11. Bracken AP, Kleine-Kohlbrecher D, Dietrich N, Pasini D, Gargiulo G, Beekman C, Theilgaard-Monch K, Minucci S, Porse BT, Marine JC, Hansen KH, and Helin K. The Polycomb group proteins bind throughout the INK4AARF locus and are disassociated in senescent cells. Genes Dev 21: 525-530, 2007.

12. Brooks SV and Faulkner JA. Contractile properties of skeletal muscles from young, adult and aged mice. $J$ Physiol 404: 71-82, 1988.

13. Brunk UT and Terman A. Lipofuscin: mechanisms of agerelated accumulation and influence on cell function. Free Radic Biol Med 33: 611-619, 2002.

14. Brunk UT and Terman A. The mitochondrial-lysosomal axis theory of aging: accumulation of damaged mitochondria as a result of imperfect autophagocytosis. Eur $J$ Biochem 269: 1996-2002, 2002.

15. Butow RA and Avadhani NG. Mitochondrial signaling: the retrograde response. Mol Cell 14: 1-15, 2004.

16. Calabrese V, Mallette FA, Deschenes-Simard X, Ramanathan S, Gagnon J, Moores A, Ilangumaran S, and Ferbeyre G. SOCS1 links cytokine signaling to p53 and senescence. Mol Cell 36: 754-767, 2009.

17. Campisi J and d'Adda di Fagagna F. Cellular senescence: when bad things happen to good cells. Nat Rev Mol Cell Biol 8: 729-740, 2007.

18. Capell BC, Drake AM, Zhu J, Shah PP, Dou Z, Dorsey J, Simola DF, Donahue G, Sammons M, Rai TS, Natale C, Ridky TW, Adams PD, and Berger SL. MLL1 is essential for the senescence-associated secretory phenotype. Genes Dev 30: 321-336, 2016.

19. Carroll B, Nelson G, Rabanal-Ruiz Y, Kucheryavenko O, Dunhill-Turner NA, Chesterman CC, Zahari Q, Zhang T, Conduit SE, Mitchell CA, Maddocks ODK, Lovat P, von Zglinicki T, and Korolchuk VI. Persistent mTORC1 signaling in cell senescence results from defects in amino acid and growth factor sensing. J Cell Biol 216: 19491957, 2017.

20. Chen YW, Harris RA, Hatahet Z, and Chou KM. Ablation of XP-V gene causes adipose tissue senescence and metabolic abnormalities. Proc Natl Acad Sci U S A 112: E4556-E4564, 2015.

21. Chicas A, Wang X, Zhang C, McCurrach M, Zhao Z, Mert O, Dickins RA, Narita $M$, Zhang $M$, and Lowe SW. Dissecting the unique role of the retinoblastoma tumor suppressor during cellular senescence. Cancer Cell 17: 376-387, 2010.

22. Coppe JP, Desprez PY, Krtolica A, and Campisi J. The senescence-associated secretory phenotype: the dark side of tumor suppression. Annu Rev Pathol 5: 99-118, 2010.

23. Coppe JP, Patil CK, Rodier F, Sun Y, Munoz DP, Goldstein J, Nelson PS, Desprez PY, and Campisi J. Senescence-associated secretory phenotypes reveal cellnonautonomous functions of oncogenic RAS and the p53 tumor suppressor. PLoS Biol 6: 2853-2868, 2008.

24. Correia-Melo C, Marques FD, Anderson R, Hewitt G, Hewitt R, Cole J, Carroll BM, Miwa S, Birch J, Merz A, Rushton MD, Charles M, Jurk D, Tait SW, Czapiewski R, 
Greaves L, Nelson G, Bohlooly YM, Rodriguez-Cuenca S, Vidal-Puig A, Mann D, Saretzki G, Quarato G, Green DR, Adams PD, von Zglinicki T, Korolchuk VI, and Passos JF. Mitochondria are required for pro-ageing features of the senescent phenotype. EMBO J 35: 724 742, 2016.

25. Criscione SW, Teo YV, and Neretti N. The chromatin landscape of cellular senescence. Trends Genet 32: 751761, 2016.

26. Cruickshanks HA, McBryan T, Nelson DM, Vanderkraats ND, Shah PP, van Tuyn J, Singh Rai T, Brock C, Donahue G, Dunican DS, Drotar ME, Meehan RR, Edwards JR, Berger SL, and Adams PD. Senescent cells harbour features of the cancer epigenome. Nat Cell Biol 15: 14951506, 2013.

27. d'Adda di Fagagna F, Reaper PM, Clay-Farrace L, Fiegler H, Carr P, Von Zglinicki T, Saretzki G, Carter NP, and Jackson SP. A DNA damage checkpoint response in telomere-initiated senescence. Nature 426: 194-198, 2003.

28. da Silva PFL, Ogrodnik M, Kucheryavenko O, Glibert J, Miwa S, Cameron C, Ishaq A, Saretzki G, NagarajaGrellscheid S, Nelson G, and von Zglinicki T. The bystander effect contributes to the accumulation of senescent cells in vivo. Aging Cell 18: e12848, 2019.

29. Dalle S, Rossmeislova L, and Koppo K. The role of inflammation in age-related sarcopenia. Front Physiol 8: 1045, 2017.

30. Dalle Pezze P, Nelson G, Otten EG, Korolchuk VI, Kirkwood TB, von Zglinicki T, and Shanley DP. Dynamic modelling of pathways to cellular senescence reveals strategies for targeted interventions. PLoS Comput Biol 10: e1003728, 2014.

31. Davalos AR, Coppe JP, Campisi J, and Desprez PY. Senescent cells as a source of inflammatory factors for tumor progression. Cancer Metastasis Rev 29: 273-283, 2010.

32. Davalos AR, Kawahara M, Malhotra GK, Schaum N, Huang J, Ved U, Beausejour CM, Coppe JP, Rodier F, and Campisi J. p53-dependent release of Alarmin HMGB1 is a central mediator of senescent phenotypes. J Cell Biol 201: 613-629, 2013.

33. Demaria M, Ohtani N, Youssef SA, Rodier F, Toussaint W, Mitchell JR, Laberge RM, Vijg J, Van Steeg H, Dolle ME, Hoeijmakers JH, de Bruin A, Hara E, and Campisi J. An essential role for senescent cells in optimal wound healing through secretion of PDGF-AA. Dev Cell 31: 722-733, 2014.

34. Demidenko ZN, Zubova SG, Bukreeva EI, Pospelov VA, Pospelova TV, and Blagosklonny MV. Rapamycin decelerates cellular senescence. Cell Cycle 8: 1888-1895, 2009.

35. Denoyelle C, Abou-Rjaily G, Bezrookove V, Verhaegen M, Johnson TM, Fullen DR, Pointer JN, Gruber SB, Su LD, Nikiforov MA, Kaufman RJ, Bastian BC, and Soengas MS. Anti-oncogenic role of the endoplasmic reticulum differentially activated by mutations in the MAPK pathway. Nat Cell Biol 8: 1053-1063, 2006.

36. Doksani $\mathrm{Y}$ and de Lange T. The role of double-strand break repair pathways at functional and dysfunctional telomeres. Cold Spring Harb Perspect Biol 6: a016576, 2014.

37. Dou Z, Xu C, Donahue G, Shimi T, Pan JA, Zhu J, Ivanov A, Capell BC, Drake AM, Shah PP, Catanzaro JM,
Ricketts MD, Lamark T, Adam SA, Marmorstein R, Zong WX, Johansen T, Goldman RD, Adams PD, and Berger SL. Autophagy mediates degradation of nuclear lamina. Nature 527: 105-109, 2015.

38. Farr JN, Fraser DG, Wang H, Jaehn K, Ogrodnik MB, Weivoda MM, Drake MT, Tchkonia T, LeBrasseur NK, Kirkland JL, Bonewald LF, Pignolo RJ, Monroe DG, and Khosla S. Identification of senescent cells in the bone microenvironment. J Bone Miner Res 31: 1920-1929, 2016.

39. Fitts RH, Booth FW, Winder WW, and Holloszy JO. Skeletal muscle respiratory capacity, endurance, and glycogen utilization. Am J Physiol 228: 1029-1033, 1975.

40. Freund A, Laberge RM, Demaria M, and Campisi J. Lamin B1 loss is a senescence-associated biomarker. Mol Biol Cell 23: 2066-2075, 2012.

41. Freund A, Patil CK, and Campisi J. p38MAPK is a novel DNA damage response-independent regulator of the senescence-associated secretory phenotype. EMBO J 30: 1536-1548, 2011.

42. Fumagalli M, Rossiello F, Clerici M, Barozzi S, Cittaro D, Kaplunov JM, Bucci G, Dobreva M, Matti V, Beausejour CM, Herbig U, Longhese MP, d'Adda di and Fagagna F. Telomeric DNA damage is irreparable and causes persistent DNA-damage-response activation. Nat Cell Biol 14: 355-365, 2012.

43. Garnham JO, Roberts LD, Caspi T, Al-Owais MM, Bullock M, Swoboda PP, Koshy A, Gierula J, Paton MF, Cubbon RM, Kearney MT, Bowen TS, and Witte KK. Divergent skeletal muscle mitochondrial phenotype between male and female patients with chronic heart failure. J Cachexia Sarcopenia Muscle 11: 79-88, 2019.

44. Georgakopoulou EA, Tsimaratou K, Evangelou K, Fernandez Marcos PJ, Zoumpourlis V, Trougakos IP, Kletsas D, Bartek J, Serrano M, and Gorgoulis VG. Specific lipofuscin staining as a novel biomarker to detect replicative and stress-induced senescence. A method applicable in cryo-preserved and archival tissues. Aging (Albany NY) 5: 37-50, 2013.

45. Gil J and Peters G. Regulation of the INK4b-ARF-INK4a tumour suppressor locus: all for one or one for all. Nat Rev Mol Cell Biol 7: 667-677, 2006.

46. Giorgio M, Migliaccio E, Orsini F, Paolucci D, Moroni M, Contursi C, Pelliccia G, Luzi L, Minucci S, Marcaccio M, Pinton P, Rizzuto R, Bernardi P, Paolucci F, and Pelicci PG. Electron transfer between cytochrome $\mathrm{c}$ and p66Shc generates reactive oxygen species that trigger mitochondrial apoptosis. Cell 122: 221-233, 2005.

47. Gomes AP, Price NL, Ling AJ, Moslehi JJ, Montgomery MK, Rajman L, White JP, Teodoro JS, Wrann CD, Hubbard BP, Mercken EM, Palmeira CM, de Cabo R, Rolo AP, Turner N, Bell EL, and Sinclair DA. Declining $\mathrm{NAD}(+)$ induces a pseudohypoxic state disrupting nuclear-mitochondrial communication during aging. Cell 155: 1624-1638, 2013.

48. Gorgoulis VG, Adams PD, Alimonti A, Bennett DC, Bischof O, Bishop C, Campisi J, Collado M, Evangelou K, Ferbeyre G, Gil J, Hara E, Krzishanovsky V, Jurk D, Maier AB, Narita M, Niedernhofer LJ, Passos JF, Robbins PD, Schmitt CA, Sedivy JM, Vougas K, von Zglinicki T, Zhou D, Serrano M, and Demaria M. Cellular senescence: defining a path forward. Cell 179: 813-827, 2019.

49. Gouspillou G, Bourdel-Marchasson I, Rouland R, Calmettes G, Franconi JM, Deschodt-Arsac V, and Diolez 
P. Alteration of mitochondrial oxidative phosphorylation in aged skeletal muscle involves modification of adenine nucleotide translocator. Biochim Biophys Acta 1797: 143$151,2010$.

50. Hayflick L and Moorhead PS. The serial cultivation of human diploid cell strains. Exp Cell Res 25: 585-621, 1961.

51. Hewitt G, Jurk D, Marques FD, Correia-Melo C, Hardy T, Gackowska A, Anderson R, Taschuk M, Mann J, and Passos JF. Telomeres are favoured targets of a persistent DNA damage response in ageing and stress-induced senescence. Nat Commun 3: 708, 2012.

52. Hoare M, Ito Y, Kang TW, Weekes MP, Matheson NJ, Patten DA, Shetty S, Parry AJ, Menon S, Salama R, Antrobus R, Tomimatsu K, Howat W, Lehner PJ, Zender L, and Narita M. NOTCH1 mediates a switch between two distinct secretomes during senescence. Nat Cell Biol 18: 979-992, 2016.

53. Hohn A and Grune T. Lipofuscin: formation, effects and role of macroautophagy. Redox Biol 1: 140-144, 2013.

54. Ishaq A, Schroder J, Edwards N, von Zglinicki T, and Saretzki G. Dietary restriction ameliorates age-related increase in DNA damage, senescence and inflammation in mouse adipose tissue. J Nutr Health Aging 22: 555-561, 2018.

55. Jacobs JJ, Kieboom K, Marino S, DePinho RA, and van Lohuizen $\mathrm{M}$. The oncogene and Polycomb-group gene bmi-1 regulates cell proliferation and senescence through the ink4a locus. Nature 397: 164-168, 1999.

56. Jeon $\mathrm{OH}$, Kim C, Laberge RM, Demaria M, Rathod S, Vasserot AP, Chung JW, Kim DH, Poon Y, David N, Baker DJ, van Deursen JM, Campisi J, and Elisseeff JH. Local clearance of senescent cells attenuates the development of post-traumatic osteoarthritis and creates a proregenerative environment. Nat Med 23: 775-781, 2017.

57. Jeon OH, Wilson DR, Clement CC, Rathod S, Cherry C, Powell B, Lee Z, Khalil AM, Green JJ, Campisi J, Santambrogio L, Witwer KW, and Elisseeff JH. Senescence cell-associated extracellular vesicles serve as osteoarthritis disease and therapeutic markers. JCI Insight 4: pii: 125019, 2019.

58. Johnson ML, Robinson MM, and Nair KS. Skeletal muscle aging and the mitochondrion. Trends Endocrinol Metab 24: 247-256, 2013.

59. Jung SH, Hwang HJ, Kang D, Park HA, Lee HC, Jeong D, Lee K, Park HJ, Ko YG, and Lee JS. mTOR kinase leads to PTEN-loss-induced cellular senescence by phosphorylating p53. Oncogene 38: 1639-1650, 2019.

60. Jurk D, Wang C, Miwa S, Maddick M, Korolchuk V, Tsolou A, Gonos ES, Thrasivoulou C, Saffrey MJ, Cameron K, and von Zglinicki T. Postmitotic neurons develop a $\mathrm{p} 21$-dependent senescence-like phenotype driven by a DNA damage response. Aging Cell 11: 996-1004, 2012.

61. Jurk D, Wilson C, Passos JF, Oakley F, Correia-Melo C, Greaves L, Saretzki G, Fox C, Lawless C, Anderson R, Hewitt G, Pender SL, Fullard N, Nelson G, Mann J, van de Sluis B, Mann DA, and von Zglinicki T. Chronic inflammation induces telomere dysfunction and accelerates ageing in mice. Nat Commun 2: 4172, 2014.

62. Kang HT, Lee KB, Kim SY, Choi HR, and Park SC. Autophagy impairment induces premature senescence in primary human fibroblasts. PLoS One 6: e23367, 2011.
63. Kim WY and Sharpless NE. The regulation of INK4/ARF in cancer and aging. Cell 127: 265-275, 2006.

64. Korolchuk VI, Miwa S, Carroll B, and von Zglinicki T. Mitochondria in cell senescence: is mitophagy the weakest link? EBioMedicine 21: 7-13, 2017.

65. Krishnamurthy J, Torrice C, Ramsey MR, Kovalev GI, Al-Regaiey K, Su L, and Sharpless NE. Ink4a/Arf expression is a biomarker of aging. J Clin Invest 114: 12991307, 2004.

66. Kuilman T, Michaloglou C, Vredeveld LC, Douma S, van Doorn R, Desmet CJ, Aarden LA, Mooi WJ, and Peeper DS. Oncogene-induced senescence relayed by an interleukin-dependent inflammatory network. Cell 133: 1019-1031, 2008.

67. Laberge RM, Awad P, Campisi J, and Desprez PY. Epithelial-mesenchymal transition induced by senescent fibroblasts. Cancer Microenviron 5: 39-44, 2012.

68. Landi F, Cruz-Jentoft AJ, Liperoti R, Russo A, Giovannini S, Tosato M, Capoluongo E, Bernabei R, and Onder G. Sarcopenia and mortality risk in frail older persons aged 80 years and older: results from ilSIRENTE study. Age Ageing 42: 203-209, 2013.

69. Lebiedzinska M, Duszynski J, Rizzuto R, Pinton P, and Wieckowski MR. Age-related changes in levels of p66Shc and serine 36-phosphorylated p66Shc in organs and mouse tissues. Arch Biochem Biophys 486: 73-80, 2009.

70. Lee $\mathrm{HC}$, Yin $\mathrm{PH}$, Chi $\mathrm{CW}$, and Wei $\mathrm{YH}$. Increase in mitochondrial mass in human fibroblasts under oxidative stress and during replicative cell senescence. J Biomed Sci 9: 517-526, 2002.

71. Lempiainen $\mathrm{H}$ and Halazonetis TD. Emerging common themes in regulation of PIKKs and PI3Ks. EMBO J 28: 3067-3073, 2009.

72. Lexell J. Human aging, muscle mass, and fiber type composition. J Gerontol A Biol Sci Med Sci 50 Spec No: 11-16, 1995.

73. Lexell J, Downham D, and Sjostrom M. Distribution of different fibre types in human skeletal muscles. Fibre type arrangement in $\mathrm{m}$. vastus lateralis from three groups of healthy men between 15 and 83 years. J Neurol Sci 72: 211-222, 1986.

74. Lexell J, Taylor CC, and Sjostrom M. What is the cause of the ageing atrophy? Total number, size and proportion of different fiber types studied in whole vastus lateralis muscle from 15- to 83-year-old men. J Neurol Sci 84: 275-294, 1988.

75. Li F, Huang Q, Chen J, Peng Y, Roop DR, Bedford JS, and Li CY. Apoptotic cells activate the "phoenix rising" pathway to promote wound healing and tissue regeneration. Sci Signal 3: ra13, 2010.

76. Li YP, Schwartz RJ, Waddell ID, Holloway BR, and Reid MB. Skeletal muscle myocytes undergo protein loss and reactive oxygen-mediated NF-kappaB activation in response to tumor necrosis factor alpha. FASEB J 12: 871880, 1998.

77. Liu Y, Zhu H, Yan X, Gu H, Gu Z, and Liu F. Endoplasmic reticulum stress participates in the progress of senescence and apoptosis of osteoarthritis chondrocytes. Biochem Biophys Res Commun 491: 368-373, 2017.

78. Ljubicic V and Hood DA. Diminished contractioninduced intracellular signaling towards mitochondrial 
biogenesis in aged skeletal muscle. Aging Cell 8: 394 404, 2009.

79. Lopes-Paciencia S, Saint-Germain E, Rowell MC, Ruiz $\mathrm{AF}$, Kalegari P, and Ferbeyre G. The senescenceassociated secretory phenotype and its regulation. Cytokine 117: 15-22, 2019.

80. Lovejoy CA and Cortez D. Common mechanisms of PIKK regulation. DNA Repair (Amst) 8: 1004-1008, 2009.

81. Mai S, Muster B, Bereiter-Hahn J, and Jendrach M. Autophagy proteins LC3B, ATG5 and ATG12 participate in quality control after mitochondrial damage and influence lifespan. Autophagy 8: 47-62, 2012.

82. Mallette FA and Ferbeyre G. The DNA damage signaling pathway connects oncogenic stress to cellular senescence. Cell Cycle 6: 1831-1836, 2007.

83. Mansouri A, Muller FL, Liu Y, Ng R, Faulkner J, Hamilton M, Richardson A, Huang TT, Epstein CJ, and Van Remmen H. Alterations in mitochondrial function, hydrogen peroxide release and oxidative damage in mouse hind-limb skeletal muscle during aging. Mech Ageing Dev 127: 298-306, 2006.

84. Martin-Ruiz C, Saretzki G, Petrie J, Ladhoff J, Jeyapalan J, Wei W, Sedivy J, and von Zglinicki T. Stochastic variation in telomere shortening rate causes heterogeneity of human fibroblast replicative life span. J Biol Chem 279: 17826-17833, 2004.

85. McArdle A and Jackson MJ. The role of attenuated redox and heat shock protein responses in the age-related decline in skeletal muscle mass and function. Essays Biochem 61: 339-348, 2017.

86. McKay BR, Ogborn DI, Baker JM, Toth KG, Tarnopolsky MA, and Parise G. Elevated SOCS3 and altered IL-6 signaling is associated with age-related human muscle stem cell dysfunction. Am J Physiol Cell Physiol 304: C717-C728, 2013.

87. Mendelsohn AR and Larrick JW. Cellular senescence as the key intermediate in tau-mediated neurodegeneration. RejuvenationRes 21: 572-579, 2018.

88. Merritt EK, Stec MJ, Thalacker-Mercer A, Windham ST, Cross JM, Shelley DP, Craig Tuggle S, Kosek DJ, Kim JS, and Bamman MM. Heightened muscle inflammation susceptibility may impair regenerative capacity in aging humans. J Appl Physiol (1985) 115: 937-948, 2013.

89. Mikkelsen UR, Agergaard J, Couppe C, Grosset JF, Karlsen A, Magnusson SP, Schjerling P, Kjaer M, and Mackey AL. Skeletal muscle morphology and regulatory signalling in endurance-trained and sedentary individuals: the influence of ageing. Exp Gerontol 93: 54-67, 2017.

90. Milanovic M, Fan DNY, Belenki D, Dabritz JHM, Zhao Z, Yu Y, Dorr JR, Dimitrova L, Lenze D, Monteiro Barbosa IA, Mendoza-Parra MA, Kanashova T, Metzner M, Pardon K, Reimann M, Trumpp A, Dorken B, Zuber J, Gronemeyer H, Hummel M, Dittmar G, Lee S, and Schmitt CA. Senescence-associated reprogramming promotes cancer stemness. Nature 553: 96-100, 2018.

91. Milanovic M, Yu Y, and Schmitt CA. The senescencestemness alliance-a cancer-hijacked regeneration principle. Trends Cell Biol 28: 1049-1061, 2018.

92. Miwa S, Czapiewski R, Wan T, Bell A, Hill KN, von Zglinicki T, and Saretzki G. Decreased mTOR signalling reduces mitochondrial ROS in brain via accumulation of the telomerase protein TERT within mitochondria. Aging (Albany NY) 8: 2551-2567, 2016.
93. Miwa S, Jow H, Baty K, Johnson A, Czapiewski R, Saretzki G, Treumann A, and von Zglinicki T. Low abundance of the matrix arm of complex I in mitochondria predicts longevity in mice. Nat Commun 5: 3837, 2014.

94. Moiseeva O, Deschenes-Simard X, St-Germain E, Igelmann S, Huot G, Cadar AE, Bourdeau V, Pollak MN, and Ferbeyre G. Metformin inhibits the senescence-associated secretory phenotype by interfering with IKK/NF-kappaB activation. Aging Cell 12: 489-498, 2013.

95. Mosteiro L, Pantoja C, Alcazar N, Marion RM, Chondronasiou D, Rovira M, Fernandez-Marcos PJ, MunozMartin M, Blanco-Aparicio C, Pastor J, Gomez-Lopez G, De Martino A, Blasco MA, Abad M, and Serrano M. Tissue damage and senescence provide critical signals for cellular reprogramming in vivo. Science 354, 2016.

96. Munoz-Espin D, Canamero M, Maraver A, Gomez-Lopez G, Contreras J, Murillo-Cuesta S, Rodriguez-Baeza A, Varela-Nieto I, Ruberte J, Collado M, and Serrano M. Programmed cell senescence during mammalian embryonic development. Cell 155: 1104-1118, 2013.

97. Murgia M, Toniolo L, Nagaraj N, Ciciliot S, Vindigni V, Schiaffino S, Reggiani C, and Mann M. Single muscle fiber proteomics reveals fiber-type-specific features of human muscle aging. Cell Rep 19: 2396-2409, 2017.

98. Musi N, Valentine JM, Sickora KR, Baeuerle E, Thompson CS, Shen Q, and Orr ME. Tau protein aggregation is associated with cellular senescence in the brain. Aging Cell 17: e12840, 2018.

99. Nacarelli T, Azar A, and Sell C. Aberrant mTOR activation in senescence and aging: a mitochondrial stress response? Exp Gerontol 68: 66-70, 2015.

100. Narita M, Nunez S, Heard E, Narita M, Lin AW, Hearn SA, Spector DL, Hannon GJ, and Lowe SW. Rb-mediated heterochromatin formation and silencing of E2F target genes during cellular senescence. Cell 113: 703-716, 2003.

101. Narita M, Young AR, Arakawa S, Samarajiwa SA, Nakashima T, Yoshida S, Hong S, Berry LS, Reichelt S, Ferreira M, Tavare S, Inoki K, Shimizu S, and Narita M. Spatial coupling of mTOR and autophagy augments secretory phenotypes. Science 332: 966-970, 2011.

102. Nielsen S and Pedersen BK. Skeletal muscle as an immunogenic organ. Curr Opin Pharmacol 8: 346-351, 2008.

103. Ock S, Lee WS, Ahn J, Kim HM, Kang H, Kim HS, Jo D, Abel ED, Lee TJ, and Kim J. Deletion of IGF-1 receptors in cardiomyocytes attenuates cardiac aging in male mice. Endocrinology 157: 336-345, 2016.

104. Oubaha M, Miloudi K, Dejda A, Guber V, Mawambo G, Germain MA, Bourdel G, Popovic N, Rezende FA, Kaufman RJ, Mallette FA, and Sapieha P. Senescenceassociated secretory phenotype contributes to pathological angiogenesis in retinopathy. Sci Transl Med 8: 362ra144, 2016.

105. Palomero J, Vasilaki A, Pye D, McArdle A, and Jackson MJ. Aging increases the oxidation of dichlorohydrofluorescein in single isolated skeletal muscle fibers at rest, but not during contractions. Am J Physiol Regul Integr Comp Physiol 305: R351-R358, 2013.

106. Passos JF, Nelson G, Wang C, Richter T, Simillion C, Proctor CJ, Miwa S, Olijslagers S, Hallinan J, Wipat A, Saretzki G, Rudolph KL, Kirkwood TB, von and Zglinicki T. Feedback between p21 and reactive oxygen 
production is necessary for cell senescence. Mol Syst Biol 6: 347, 2010.

107. Passos JF, Saretzki G, Ahmed S, Nelson G, Richter T, Peters H, Wappler I, Birket MJ, Harold G, Schaeuble K, Birch-Machin MA, Kirkwood TB, and von Zglinicki T. Mitochondrial dysfunction accounts for the stochastic heterogeneity in telomere-dependent senescence. PLoS Biol 5: e110, 2007.

108. Petersen S, Saretzki G, and von Zglinicki T. Preferential accumulation of single-stranded regions in telomeres of human fibroblasts. Exp Cell Res 239: 152-160, 1998.

109. Porter MM, Vandervoort AA, and Lexell J. Aging of human muscle: structure, function and adaptability. Scand J Med Sci Sports 5: 129-142, 1995.

110. Przybyla B, Gurley C, Harvey JF, Bearden E, Kortebein P, Evans WJ, Sullivan DH, Peterson CA, and Dennis RA. Aging alters macrophage properties in human skeletal muscle both at rest and in response to acute resistance exercise. Exp Gerontol 41: 320-327, 2006.

111. Richardson GD, Laval S, and Owens WA. Cardiomyocyte regeneration in the mdx mouse model of nonischemic cardiomyopathy. Stem Cells Dev 24: 1672-1679, 2015.

112. Richter T, Saretzki G, Nelson G, Melcher M, Olijslagers $\mathrm{S}$, and von Zglinicki T. TRF2 overexpression diminishes repair of telomeric single-strand breaks and accelerates telomere shortening in human fibroblasts. Mech Ageing Dev 128: 340-345, 2007.

113. Rivas DA, Morris EP, Haran PH, Pasha EP, Morais Mda S, Dolnikowski GG, Phillips EM, and Fielding RA. Increased ceramide content and NFkappaB signaling may contribute to the attenuation of anabolic signaling after resistance exercise in aged males. J Appl Physiol (1985) 113: 1727-1736, 2012.

114. Sapieha P and Mallette FA. Cellular senescence in postmitotic cells: beyond growth arrest. Trends Cell Biol 28: 595-607, 2018.

115. Scaffidi $P$ and Misteli T. Lamin A-dependent nuclear defects in human aging. Science 312: 1059-1063, 2006.

116. Schiaffino $\mathrm{S}$ and Reggiani C. Fiber types in mammalian skeletal muscles. Physiol Rev 91: 1447-1531, 2011.

117. Schmitt CA, Fridman JS, Yang M, Lee S, Baranov E, Hoffman RM, and Lowe SW. A senescence program controlled by $\mathrm{p} 53$ and p16INK4a contributes to the outcome of cancer therapy. Cell 109: 335-346, 2002.

118. Senyo SE, Steinhauser ML, Pizzimenti CL, Yang VK, Cai L, Wang M, Wu TD, Guerquin-Kern JL, Lechene CP, and Lee RT. Mammalian heart renewal by pre-existing cardiomyocytes. Nature 493: 433-436, 2013.

119. Serrano M, Lin AW, McCurrach ME, Beach D, and Lowe SW. Oncogenic ras provokes premature cell senescence associated with accumulation of p53 and p16INK4a. Cell 88: 593-602, 1997.

120. Shah PP, Donahue G, Otte GL, Capell BC, Nelson DM, Cao K, Aggarwala V, Cruickshanks HA, Rai TS, McBryan T, Gregory BD, Adams PD, and Berger SL. Lamin B1 depletion in senescent cells triggers large-scale changes in gene expression and the chromatin landscape. Genes Dev 27: 1787-1799, 2013.

121. Short S, Fielder E, Miwa S, and von Zglinicki T. Senolytics and senostatics as adjuvant tumour therapy. EBioMedicine 41: 683-692, 2019.

122. Sitte N, Huber M, Grune T, Ladhoff A, Doecke WD, Von Zglinicki T, and Davies KJ. Proteasome inhibition by lipofuscin/ceroid during postmitotic aging of fibroblasts FASEB J 14: 1490-1498, 2000.

123. Sitte N, Merker K, Grune T, and von Zglinicki T. Lipofuscin accumulation in proliferating fibroblasts in vitro: an indicator of oxidative stress. Exp Gerontol 36: 475-486, 2001.

124. Sitte N, Merker K, Von Zglinicki T, Grune T, and Davies KJ. Protein oxidation and degradation during cellular senescence of human BJ fibroblasts: part I-effects of proliferative senescence. FASEB $J$ 14: 2495-2502, 2000.

125. Storer M, Mas A, Robert-Moreno A, Pecoraro M, Ortells MC, Di Giacomo V, Yosef R, Pilpel N, Krizhanovsky V, Sharpe J, and Keyes WM. Senescence is a developmental mechanism that contributes to embryonic growth and patterning. Cell 155: 1119-1130, 2013.

126. Tai H, Wang Z, Gong H, Han X, Zhou J, Wang X, Wei X, Ding Y, Huang N, Qin J, Zhang J, Wang S, Gao F, Chrzanowska-Lightowlers ZM, Xiang R, and Xiao $\mathrm{H}$. Autophagy impairment with lysosomal and mitochondrial dysfunction is an important characteristic of oxidative stress-induced senescence. Autophagy 13: 99-113, 2017.

127. Takahashi A, Okada R, Nagao K, Kawamata Y, Hanyu A, Yoshimoto S, Takasugi M, Watanabe S, Kanemaki MT, Obuse C, and Hara E. Exosomes maintain cellular homeostasis by excreting harmful DNA from cells. Nat Commun 8: 15287, 2017.

128. Tchkonia T, Morbeck DE, Von Zglinicki T, Van Deursen J, Lustgarten J, Scrable H, Khosla S, Jensen MD, and Kirkland JL. Fat tissue, aging, and cellular senescence. Aging Cell 9: 667-684, 2010.

129. Toussaint O, Medrano EE, and von Zglinicki T. Cellular and molecular mechanisms of stress-induced premature senescence (SIPS) of human diploid fibroblasts and melanocytes. Exp Gerontol 35: 927-945, 2000.

130. von Zglinicki T. Oxidative stress shortens telomeres. Trends Biochem Sci 27: 339-344, 2002.

131. von Zglinicki T, Saretzki G, Docke W, and Lotze C. Mild hyperoxia shortens telomeres and inhibits proliferation of fibroblasts: a model for senescence? Exp Cell Res 220: 186-193, 1995.

132. von Zglinicki T, Saretzki G, Ladhoff J, d'Adda di Fagagna $\mathrm{F}$, and Jackson SP. Human cell senescence as a DNA damage response. Mech Ageing Dev 126: 111-117, 2005.

133. Was H, Czarnecka J, Kominek A, Barszcz K, Bernas T, Piwocka K, and Kaminska B. Some chemotherapeuticstreated colon cancer cells display a specific phenotype being a combination of stem-like and senescent cell features. Cancer Biol Ther 19: 63-75, 2018.

134. Whitham $\mathrm{M}$ and Febbraio MA. The ever-expanding myokinome: discovery challenges and therapeutic implications. Nat Rev Drug Discov 15: 719-729, 2016.

135. Xu M, Palmer AK, Ding H, Weivoda MM, Pirtskhalava T, White TA, Sepe A, Johnson KO, Stout MB, Giorgadze N, Jensen MD, LeBrasseur NK, Tchkonia T, and Kirkland JL. Targeting senescent cells enhances adipogenesis and metabolic function in old age. Elife 4: e12997, 2015.

136. Yang Z, Kodama S, Suzuki K, and Watanabe M. Telomerase activity, telomere length, and chromosome aberrations in the extension of life span of human embryo cells induced by low-dose X-rays. J Radiat Res 39: 35-51, 1998. 
137. Young A and Skelton DA. Applied physiology of strength and power in old age. Int J Sports Med 15: 149-151, 1994.

138. Young AR, Narita M, Ferreira M, Kirschner K, Sadaie M, Darot JF, Tavare S, Arakawa S, Shimizu S, Watt FM, and Narita M. Autophagy mediates the mitotic senescence transition. Genes Dev 23: 798-803, 2009.

139. Zhang $\mathrm{H}$, Hoff $\mathrm{H}$, Marinucci $\mathrm{T}$, Cristofalo VJ, and Sell C. Mitogen-independent phosphorylation of S6K1 and decreased ribosomal S6 phosphorylation in senescent human fibroblasts. Exp Cell Res 259: 284-292, 2000.

140. Zhu Y, Tchkonia T, Pirtskhalava T, Gower AC, Ding H, Giorgadze N, Palmer AK, Ikeno Y, Hubbard GB, Lenburg M, O'Hara SP, LaRusso NF, Miller JD, Roos CM, Verzosa GC, LeBrasseur NK, Wren JD, Farr JN, Khosla S, Stout MB, McGowan SJ, Fuhrmann-Stroissnigg H, Gurkar AU, Zhao J, Colangelo D, Dorronsoro A, Ling YY, Barghouthy AS, Navarro DC, Sano T, Robbins PD, Niedernhofer LJ, and Kirkland JL. The Achilles' heel of senescent cells: from transcriptome to senolytic drugs. Aging Cell 14: 644-658, 2015.

Address correspondence to: Prof. Thomas von Zglinicki Ageing Research Laboratories Faculty of Medical Sciences Biosciences Institute Newcastle University Campus for Ageing and Vitality Newcastle upon Tyne NE4 5PL United Kingdom

E-mail: t.vonzglinicki@ncl.ac.uk

Date of first submission to ARS Central, February 13, 2020; date of acceptance, March 9, 2020.

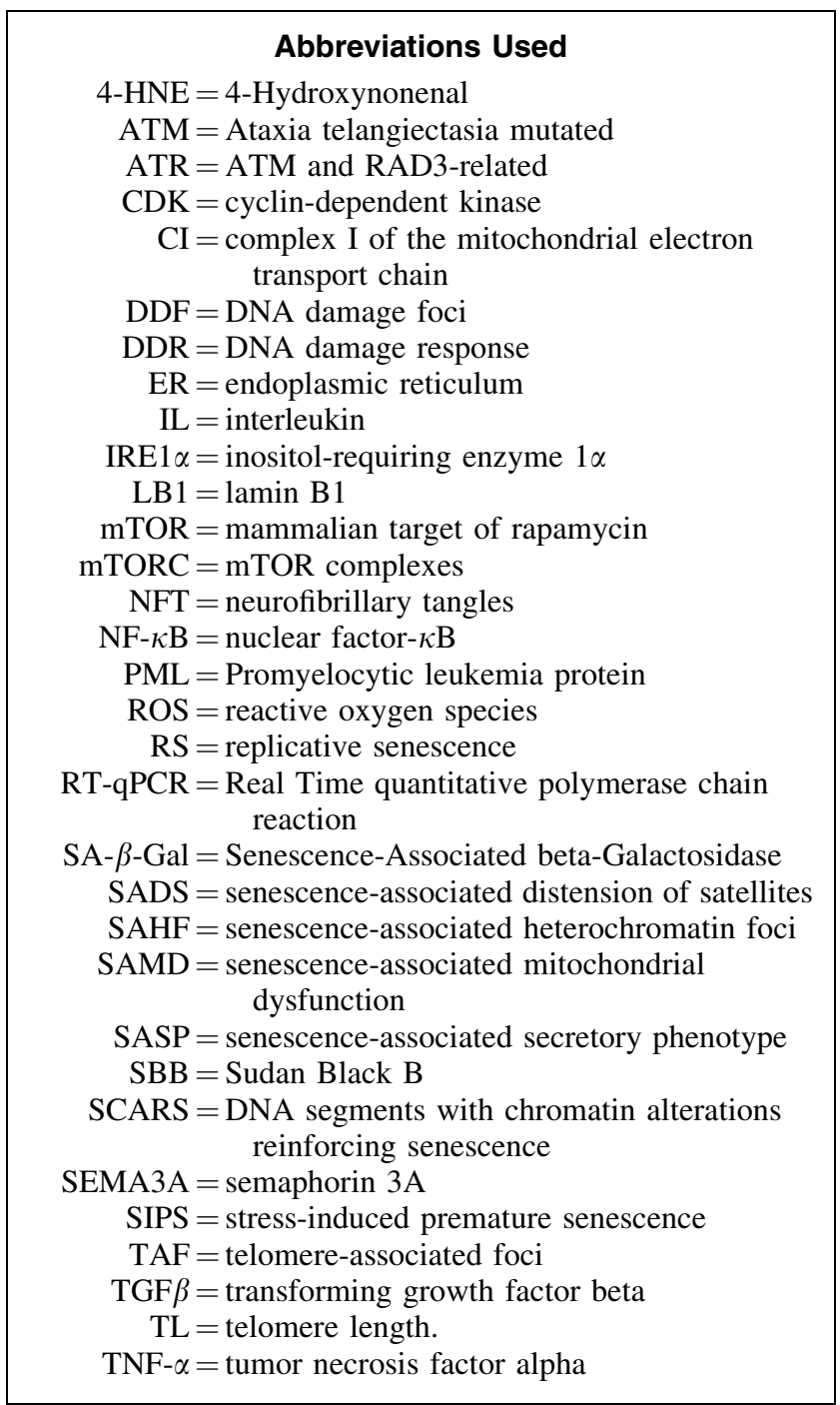

